\title{
Vegetation dynamics and human activity in the Western Pyrenean Region during the Holocene
}

\author{
S. Pérez-Díaz a, b, *, J.A. López-Sáez ${ }^{\text {, }}$, D. Galop ${ }^{\text {a }}$ \\ ${ }^{a}$ GEODE, UMR 5602 CNRS, Université Toulouse 2 Jean Jaurès 5, Allées A. Machado, 31058, Toulouse, Cedex 9, France \\ ${ }^{\mathrm{b}}$ University of the Basque Country (UPV/EHU), Francisco Tomás y Valiente, s/n. Apdo. 2111, 01006, Vitoria-Gasteiz, Spain \\ ${ }^{c}$ Archaeobiology Group, Institute of History, Spanish National Research Council (CCHS-CSIC), Albasanz 26-28, 28037, Madrid, Spain
}

\section{A R T I C L E I N F O}

\section{Article history:}

Available online 5 November 2014

\section{Keywords:}

Pollen analysis

Vegetation

Climate

Anthropisation

Holocene

Western Pyrenees

\begin{abstract}
A B S T R A C T
The present paper summarises the evolution of the vegetation and the evidences of anthropisation in the Western Pyrenees (Northern Iberian Peninsula) during the Holocene. All the palynological studies published about this region, about both natural and archaeological deposits, have been compiled, and special attention is paid on the available radiocarbon dates. We also present new results of the palynological study of the peat bog of Atxuri (Navarre). The main results document the arboreal colonisation in the early Holocene; the first evidences of anthropisation associated with the Early Neolithic (ca. 5500 $-4500 \mathrm{cal} \mathrm{BC}$ ); the consolidation of a productive economy (agriculture and pastoralism) in the Middle/ Late Neolithic (ca. 4500-3200 cal BC) and above all in the Chalcolithic (ca. 3200-2200 cal BC); and the rise of complex urban societies in the Bronze Age (ca. 2200-900 cal BC) and Iron Age (ca. 900 $-200 \mathrm{cal} \mathrm{BC}$ ) and their impact on the vegetation.
\end{abstract}

(C) 2014 Elsevier Ltd and INQUA. All rights reserved.

\section{Introduction}

The Western Pyrenees is a region whose climate, geology, biogeography and history have resulted in a great environmental heterogeneity and biological diversity, with a noteworthy wealth of species, biological communities and ecosystems. In addition, from the viewpoint of its geographical situation, it has been on the traditional route from central and southern Europe to the inner Iberian Peninsula, as shown by the large number of archaeological remains of different periods that have been found (BarandiaránMaestu et al., 1998; Alday et al., 2006; Peñalver, 2008; FernándezEraso et al., 2009).

The current vegetation of this region has originated in different processes that have taken place over time and which have modified the structure of the forests significantly (Costa-Tenorio et al., 2005). These phenomena correspond, on one hand, to continuous environmental changes and, on the other, to the weight of a long heterogeneous human use of the territory. The latter factor, the impact of human communities on the environment, becomes particularly noticeable after $\mathrm{ca} .5500 \mathrm{cal} \mathrm{BC}$, mainly owing to the change in the

\footnotetext{
* Corresponding author. GEODE, UMR 5602 CNRS, Université Toulouse 2 Jean Jaurès 5, Allées A. Machado-31058, Toulouse, Cedex 9, France.

E-mail addresses: sebas.perezdiaz@gmail.com (S. Pérez-Díaz), joseantonio. lopez@cchs.csic.es (J.A. López-Sáez), didier.galop@univ-tlse2.fr (D. Galop).
}

ways of life of the prehistoric communities. After this time, farming practices spread across the Western Pyrenees, significantly modifying local ecosystems in both mountain and valley areas, within a process related to the Neolithisation dynamic in the Mediterranean basin (Galop et al., 2013).

To obtain an accurate picture of the phenomena involved in shaping the modern vegetation communities it is necessary to take into account all the available palaeobotanical records, especially palynological studies both from archaeological sediments and from natural deposits like peat bogs, lakes, estuaries, and so on. All these data together provide the essential information to address some issues of great interest and hot debated, such as the evolution of the main plant communities over time, the appearance/expansion/ regression of some taxa of particular interest because of their rareness, climate change and its connection with the development of the vegetation, relationships between human communities and the environment, and aspects such as the anthropisation processes associated with the Neolithic (Dupré, 1988; Birks et al., 1988; Berglund, 1991; Galop, 1998; López-Sáez et al., 2000, 2003; Barbier et al., 2001; Davis et al., 2003; Carrión et al., 2010; Vannière et al., 2011; Nieto-Moreno et al., 2011; Galop et al., 2013; Sadori et al., 2013; among others).

The first palynological research in the region took place in the 1980s when this type of study began to be widely applied both to natural deposits (Peñalba, 1989) and to archaeological ones (López- 
García, 1982; Dupré, 1984; Boyer-Klein, 1985; García-Antón et al., 1987; Peñalba, 1987; Sánchez-Goñi, 1987). Since then, more than 40 new palynological sequences have been published both in Spanish journals (Iriarte, 2006, 2009b; Pérez-Díaz and López-Sáez, 2013) and International journals (Sanchez-Goñi, 1996; Iriarte, 2009a; Corella et al., 2013).

This paper focuses on the evolution of the vegetation over the last 9500 years, in order to evaluate the anthropic impact on the landscape by prehistoric groups that inhabited the Western Pyrenees. With this objective, all the available palynological studies from the Epipaleolithic-Mesolithic to the Iron Age, and a full series of 219 radiocarbon dates, have been taken into account.

\section{Regional setting}

The Western Pyrenees is quite rugged, with great climatic and geomorphologic variety. The relief is generally aligned east-west, and therefore the area consists of a series of mountain barriers, parallel to the coastline, which limits the spread of Atlantic flora southwards. From the biogeographic point of view, it can be divided into three areas: the Atlantic zone (coastal and inner valleys of the north of the Basque Country), the Pyrenees (north of Navarre), both belonging to the Eurosiberian region, and the Transition area (SubAtlantic and Sub-Mediterranean Valleys of Álava), belonging to the Mediterranean region (Fig. 1).

The Pyrenees is a large mountain range over $400 \mathrm{~km}$ long, separating the Aquitaine basin from the Ebro valley. Its main valleys in the north of Navarre run perpendicular to the range. The climate is generally cold and wet in winter, when snow and mist are common. In contrast, summer temperatures can be relatively high. It has large well-conserved forest masses with Pinus sylvestris L. (Scots pine), Quercus robur L. (Pendunculate oak), Quercus faginea
Lam. (Portuguese oak), Fagus sylvatica L. (beech) and Abies alba Mill. (fir).

In northern Iberia, the Atlantic zone is a strip parallel to the coastline, directly influenced by the sea. It is characterised by undulating relief, with hills and wide valleys near the coast and more abrupt relief inland. The climate is very humid and temperate, with hardly any summer drought (Aseginolaza et al., 1996). The main elements in the vegetation today are anthropic, with farmlands, above all meadows, together with plantations of conifers. Stands of Quercus ilex L. (holm oak) are found in some limestone areas, and small dispersed woods with pendunculate oak and other deciduous species (Aseginolaza et al., 1996).

Finally, the climate of the Transition area displays characteristics of both Atlantic and Mediterranean environments. In high mountain areas the climate is characterised by low temperatures and heavy precipitation, with frequent mist, and frost and snow except in summer. The climatic and geomorphologic conditions result in vegetation communities consisting of calcicolous beech woods on limestone hills, together with anthropic pastures used by livestock. In the valleys, the most important vegetation types are oak woods with pendunculate oak, Quercus pyrenaica Willd. (Pyrenean oak) and small stands of Portuguese oak, together with areas of holm oak and Scots pine (Aseginolaza et al., 1996).

\section{Materials and methods}

All palynological studies published for the Holocene on the southern side of the Western Pyrenees have been examined. In total, these refer to 55 deposits, of which 7 are natural deposits and 48 are archaeological sites. They are all situated chronologically with a total of 219 absolute dates (Table 1 ).

Table 1

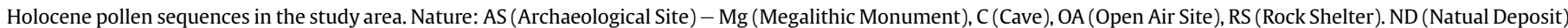

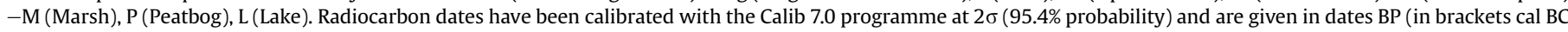
or cal AD).

\begin{tabular}{|c|c|c|c|c|c|c|}
\hline Number & Site & Location & Nature & Altitude & Age BP (Age cal BC/AD) & References \\
\hline \multicolumn{7}{|c|}{ Atlantic area } \\
\hline 1 & Aitxu & Ataun-Idiazabal & AS (Mg) & 930 & $3530 \pm 110(2196-1566 \mathrm{cal} \mathrm{BC})$ & Iriarte, $1997 \mathrm{c}$ \\
\hline 2 & Amalda & Cestona & AS (C) & 205 & $\begin{array}{l}1740 \pm 200(185 \text { cal BC }-665 \text { cal AD }), 1460 \pm 80(415 \\
-762 \text { cal AD })\end{array}$ & Dupré, 1990 \\
\hline 3 & Arenaza I & Galdames & AS (C) & 185 & $\begin{array}{l}10,300 \pm 180(10,653-9419 \mathrm{cal} \mathrm{BC}), 9600 \pm 180 \\
(9446-8354 \mathrm{cal} \mathrm{BC}), 6040 \pm 75(5207-4779 \mathrm{cal} \mathrm{BC}) \\
5755 \pm 65(4767-4457 \mathrm{cal} \mathrm{BC}), 4965 \pm 195(4259 \\
-3346 \mathrm{cal} \mathrm{BC}), 4730 \pm 110(3760-3108 \mathrm{cal} \mathrm{BC}) \\
3835 \pm 55(2466-2141 \mathrm{cal} \mathrm{BC}), 3805 \pm 70(2465 \\
-2039 \mathrm{cal} \mathrm{BC}), 3580 \pm 70(2135-1746 \mathrm{cal} \mathrm{BC})\end{array}$ & Isturiz and Sanchez-Goñi, 1990 \\
\hline 4 & Berreaga & Mungia & AS (OA) & 360 & - & Iriarte, $1994 a$ \\
\hline 5 & Buruntza & Andoain & AS (OA) & 439 & $\begin{array}{l}3000 \pm 60(1401-1055 \mathrm{cal} \mathrm{BC}), 2810 \pm 90(1253 \\
-806 \mathrm{cal} \mathrm{BC}), 2475 \pm 75(779-408 \mathrm{cal} \mathrm{BC}) \\
2270 \pm 80(706-95 \mathrm{cal} \mathrm{BC}), 2180 \pm 80(394 \\
-46 \mathrm{cal} \mathrm{BC})\end{array}$ & Iriarte, 1997b \\
\hline 6 & Ekain & Deba & AS (C) & 90 & $\begin{array}{l}9460 \pm 185(9249-8323 \mathrm{cal} \mathrm{BC}), 9540 \pm 210(9433 \\
-8295 \mathrm{cal} \mathrm{BC}), 9610 \pm 85(9247-8766 \mathrm{cal} \mathrm{BC}) \\
4960 \pm 60(3942-3641 \mathrm{cal} \mathrm{BC}), 5179 \pm 170(4338 \\
-3653 \mathrm{cal} \mathrm{BC}), 4680 \pm 60(3633-3358 \mathrm{cal} \mathrm{BC}) \\
4120 \pm 50(2876-2505 \mathrm{cal} \mathrm{BC}), 3820 \pm 240(2896 \\
-1658 \mathrm{cal} \mathrm{BC}), 3700 \pm 40(2202-1973 \mathrm{cal} \mathrm{BC})\end{array}$ & Dupré, 1984 \\
\hline 7 & Gastiburu & Arratzu & AS (OA) & 340 & $\begin{array}{l}3260 \pm 60(1681-1427 \mathrm{cal} \mathrm{BC}), 2455 \pm 26(753 \\
-412 \mathrm{cal} \mathrm{BC}), 2396 \pm 27(723-398 \mathrm{cal} \mathrm{BC}) \\
2270 \pm 26(398-211 \mathrm{cal} \mathrm{BC}), 2257 \pm 29(394 \\
-209 \mathrm{cal} \mathrm{BC}), 2233 \pm 26(386-205 \mathrm{cal} \mathrm{BC}) \\
2190 \pm 26(362-180 \mathrm{cal} \mathrm{BC}), 2157 \pm 27(357 \\
-106 \mathrm{cal} \mathrm{BC}), 2140 \pm 60(370-41 \mathrm{cal} \mathrm{BC}) \\
2076 \pm 44(201 \mathrm{cal} \mathrm{BC}-21 \mathrm{cal} \mathrm{AD}), 2060 \pm 60 \\
(345 \mathrm{cal} \mathrm{BC}-69 \mathrm{cal} \mathrm{AD}), 1759 \pm 28(176-383 \mathrm{cal} \mathrm{AD})\end{array}$ & Valdés, 2009 \\
\hline
\end{tabular}


Table 1 (continued)

\begin{tabular}{|c|c|c|c|c|c|c|}
\hline Number & Site & Location & Nature & Altitude & Age BP (Age cal BC/AD) & References \\
\hline 8 & Herriko Barra & Zarauz & AS $(O A)$ & 5 & $\begin{array}{l}5810 \pm 170(5203-4332 \mathrm{cal} \mathrm{BC}), 6010 \pm 90(5207 \\
-4713 \mathrm{cal} \mathrm{BC}), 5960 \pm 95(5204-4590 \mathrm{cal} \mathrm{BC}) \\
5730 \pm 110(4824-4352 \mathrm{cal} \mathrm{BC}), 5800 \pm 110(4933 \\
-4374 \mathrm{cal} \mathrm{BC}), 4920 \pm 100(3959-3390 \mathrm{cal} \mathrm{BC})\end{array}$ & Iriarte et al., 2004 \\
\hline 9 & Ilso Betaio & Arcentales-Sopuerta & AS (OA) & 712 & $930 \pm 80 \mathrm{BP}(981-1261$ cal AD $)$ & Iriarte, 1999a \\
\hline 10 & Intxur & Albiztur-Tolosa & AS (OA) & 742 & $\begin{array}{l}2720 \pm 80(1112-769 \mathrm{cal} \mathrm{BC}), 2400 \pm 80(782 \\
-265 \mathrm{cal} \mathrm{BC}), 2260 \pm 80(519-60 \mathrm{cal} \mathrm{BC}) \\
2180 \pm 80(394-46 \mathrm{cal} \mathrm{BC}), 2070 \pm 80(358 \mathrm{cal} \mathrm{BC} \\
-80 \mathrm{cal} \mathrm{AD}), 2030 \pm 80(352 \mathrm{cal} \mathrm{BC}-132 \mathrm{cal} \mathrm{AD})\end{array}$ & Iriarte, $1994 a$ \\
\hline 11 & Katillotxu & Mundaka & AS (Mg) & 336 & $\begin{array}{l}5200 \pm 40(4225-3948 \text { cal BC }), 4290 \pm 40(3022 \\
-2780 \text { cal BC })\end{array}$ & Iriarte, $2007 / 2009$ \\
\hline 12 & Kobaederra & Kortezubi & AS (C) & 260 & $\begin{array}{l}5630 \pm 100(4709-4270 \mathrm{cal} \mathrm{BC}), 5375 \pm 90(4359 \\
-3989 \mathrm{cal} \mathrm{BC}), 5820 \pm 240(5306-4175 \mathrm{cal} \mathrm{BC}) \\
5460 \pm 90(4460-4050 \mathrm{cal} \mathrm{BC}), 5200 \pm 110(4323 \\
-3769 \mathrm{cal} \mathrm{BC}), 4405 \pm 55(3331-2905 \mathrm{cal} \mathrm{BC})\end{array}$ & Iriarte, 2009a \\
\hline 13 & Kobeaga II & Ispster & AS (C) & 205 & $\begin{array}{l}7690 \pm 270(7295-6018 \text { cal BC), } 6945 \pm 65(5983 \\
-5718 \text { cal BC })\end{array}$ & Iriarte, 2000 \\
\hline 14 & Kosnoaga & Gernika & AS (OA) & 274 & - & Iriarte, 1994a \\
\hline 15 & La Boheriza 2 & Carranza & AS (Mg) & 732 & $\begin{array}{l}5500 \pm 100(4542-4054 \mathrm{cal} \mathrm{BC}), 5200 \pm 75(4235 \\
-3802 \mathrm{cal} \mathrm{BC})\end{array}$ & Iriarte, $1995 \mathrm{a}$ \\
\hline 16 & La Cabaña 4 & Carranza & AS (Mg) & 713 & - & Iriarte, $1999 c$ \\
\hline 17 & Laminak II & Berriatua & AS (C) & 40 & $\begin{array}{l}11,700 \pm 140(11,867-11,328 \text { cal BC }), 10,380 \pm 140 \\
(10,654-9769 \text { cal BC })\end{array}$ & Isturiz, 1994 \\
\hline 18 & Lezetxiki & Mondragón & AS (C) & 380 & - & Sanchez-Goñi, 1993 \\
\hline 19 & Mulixko Gaina & Urnieta-Hernani & AS (Mg) & 415 & $2630 \pm 90(1002-420 \mathrm{cal} \mathrm{BC})$ & Peñalba, 1987 \\
\hline 20 & Napalatza & Idiazabal & AS (Mg) & 740 & $\begin{array}{l}1830 \pm 90(1-470 \text { cal AD), } 1670 \pm 140(77 \\
-642 \text { cal AD })\end{array}$ & Iriarte, $1999 \mathrm{~b}$ \\
\hline 21 & Pareko Landa & Bermeo-Busturia & AS $(\mathrm{OA})$ & 522 & $\begin{array}{l}7510 \pm 100(6590-6107 \mathrm{cal} \mathrm{BC}), 6650 \pm 130(5793 \\
-5330 \mathrm{cal} \mathrm{BC})\end{array}$ & Iriarte et al., 2007/2008 \\
\hline 22 & Pico Ramos & Muskiz & AS (C) & 215 & $\begin{array}{l}6840 \pm 75(5890-5622 \mathrm{cal} \mathrm{BC}), 6040 \pm 90(5210 \\
-4729 \mathrm{cal} \mathrm{BC}), 5860 \pm 65(4895-4547 \mathrm{cal} \mathrm{BC}) \\
5370 \pm 40(4331-4055 \mathrm{cal} \mathrm{BC}) \\
4790 \pm 110(3910-3199 \mathrm{cal} \mathrm{BC}), 4210 \pm 110(3090 \\
-2480 \mathrm{cal} \mathrm{BC}), 4100 \pm 110(2910-2347 \mathrm{cal} \mathrm{BC})\end{array}$ & Iriarte, $1994 \mathrm{~b}$ \\
\hline 23 & Playaundi & Irún & $\mathrm{ND}(\mathrm{M})$ & 2 & $\begin{array}{l}7810 \pm 130(7044-6451 \mathrm{cal} \mathrm{BC}), 6630 \pm 120(5741 \\
-5331 \mathrm{cal} \mathrm{BC}), 6590 \pm 120(5716-5324 \mathrm{cal} \mathrm{BC}) \\
2740 \pm 90(1192-676 \mathrm{cal} \mathrm{BC})\end{array}$ & Sánchez Goñi, 1996 \\
\hline 24 & Praalata & Ataun-Idiazabal & AS (Mg) & 931 & $\begin{array}{l}4470 \pm 70(3357-2929 \text { cal BC }), 4310 \pm 110(3338 \\
-2624 \text { cal BC) }\end{array}$ & Iriarte, $1997 \mathrm{c}$ \\
\hline 25 & Saldropo & Zeanuri & $\mathrm{ND}(\mathrm{P})$ & 625 & $\begin{array}{l}5630 \pm 70(4653-4340 \mathrm{cal} \mathrm{BC}), 3590 \pm 90(2199 \\
-1694 \mathrm{cal} \mathrm{BC}), 840 \pm 50(1045-1273 \mathrm{cal} \mathrm{AD}) \\
4510 \pm 140(3629-2891 \mathrm{cal} \mathrm{BC}), 2460 \pm 100(803 \\
-387 \mathrm{cal} \mathrm{BC}), 920 \pm 100(901-1277 \mathrm{cal} \mathrm{AD})\end{array}$ & $\begin{array}{l}\text { García-Antón et al., 1987; } \\
\text { Peñalba, } 1989\end{array}$ \\
\hline 26 & Sta. María la Real & Zarauz & AS $(O A)$ & 7 & $2370 \pm 40(733-382 \mathrm{cal} \mathrm{BC})$ & Iriarte, $2009 \mathrm{~b}$ \\
\hline 27 & Santimamiñe & Kortezubi & AS (C) & 137 & $\begin{array}{l}10,100 \pm 60(10,080-9440 \mathrm{cal} \mathrm{BC}), 10,060 \pm 60 \\
(10,030-9360 \mathrm{cal} \mathrm{BC}), 7580 \pm 50(6490 \\
-6380 \mathrm{cal} \mathrm{BC}) \\
5450 \pm 50(4360-4230 \mathrm{cal} \mathrm{BC}), 5010 \pm 40(3940 \\
-3700 \mathrm{cal} \mathrm{BC}), 3710 \pm 40(2269-1977 \mathrm{cal} \mathrm{BC})\end{array}$ & Iriarte, 2011 \\
\hline 28 & Sustrigi & Areatza-Bilaro & AS $(\mathrm{OA})$ & 734 & - & $\begin{array}{l}\text { Iriarte et al., 2007/2008; } \\
\text { Iriarte, 2009a }\end{array}$ \\
\hline 29 & Unanibi & Idiazabal & AS (Mg) & 840 & $\begin{array}{l}3350 \pm 100(1886-1433 \mathrm{cal} \mathrm{BC}), 3085 \pm 75(1500 \\
-1128 \mathrm{cal} \mathrm{BC}), 3040 \pm 230(1878-789 \mathrm{cal} \mathrm{BC})\end{array}$ & Iriarte, $1999 b$ \\
\hline 30 & Urdaibai & Gernika & $\mathrm{ND}(\mathrm{M})$ & 12 & $\begin{array}{l}9050 \pm 40 \mathrm{BP}(8303-8228 \mathrm{cal} \mathrm{BC}), 2580 \pm 40(820 \\
-549 \mathrm{cal} \mathrm{BC})\end{array}$ & Iriarte et al., 2006 \\
\hline 31 & Urtiaga & Deba & AS (C) & 160 & $8700 \pm 170(8259-7484 \mathrm{cal} \mathrm{BC})$ & Sanchez-Goñi, 1993 \\
\hline 32 & Zorroztarri & Idiazabal-Segura & AS (Mg) & 678 & $\begin{array}{l}3280 \pm 90(1865-1326 \mathrm{cal} \mathrm{BC}), 3040 \pm 90(1493 \\
-1024 \mathrm{cal} \mathrm{BC})\end{array}$ & Iriarte, 1994a \\
\hline \multicolumn{7}{|c|}{ Pyrenean area } \\
\hline 33 & Abauntz & Arraiz & AS (C) & 709 & $\begin{array}{l}9530 \pm 300(9976-7992 \mathrm{cal} \mathrm{BC}), 6910 \pm 450(6247 \\
-4796 \mathrm{cal} \mathrm{BC}), 5820 \pm 40(4781-4556 \mathrm{cal} \mathrm{BC}) \\
5390 \pm 120(4452-3973 \mathrm{cal} \mathrm{BC}), 4240 \pm 140(3332 \\
-2474 \mathrm{cal} \mathrm{BC}), 4370 \pm 70(3332-2883 \mathrm{cal} \mathrm{BC}) \\
4025 \pm 35(2829-2469 \mathrm{cal} \mathrm{BC}), 3975 \pm 35(2577 \\
-2349 \mathrm{cal} \mathrm{BC}), 3900 \pm 35(2475-2244 \mathrm{cal} \mathrm{BC})\end{array}$ & López-García, 1982 \\
\hline 34 & Aizpea & Aribe & AS (RS) & 720 & $\begin{array}{l}7790 \pm 90(7024-6454 \mathrm{cal} \mathrm{BC}), 7160 \pm 70(6211 \\
-5902 \mathrm{cal} \mathrm{BC}), 6830 \pm 70(5876-5622 \mathrm{cal} \mathrm{BC}) \\
6600 \pm 50(5620-5482 \mathrm{cal} \mathrm{BC}), 6370 \pm 70(5475 \\
-5222 \mathrm{cal} \mathrm{BC})\end{array}$ & Iriarte, 2001 \\
\hline 35 & Atxuri & Maya de Baztán & $\mathrm{ND}(\mathrm{P})$ & 500 & $\begin{array}{l}2710 \pm 60(995-796 \mathrm{cal} \mathrm{BC}), 1920 \pm 80(109 \mathrm{cal} \mathrm{BC} \\
-322 \mathrm{cal} A D) \\
6370 \pm 80(5491-5081 \mathrm{cal} \mathrm{BC}), 3880 \pm 40(2470 \\
-2210 \mathrm{cal} \mathrm{BC}), 3300 \pm 40(1683-1499 \mathrm{cal} \mathrm{BC}) \\
2180 \pm 40(371-113 \mathrm{cal} \mathrm{BC})\end{array}$ & Peñalba, 1989, Galop et al., 2004 \\
\hline
\end{tabular}


Table 1 (continued)

\begin{tabular}{|c|c|c|c|c|c|c|}
\hline Number & Site & Location & Nature & Altitude & Age BP (Age cal BC/AD) & References \\
\hline 36 & Belate & Narvarte & ND (P) & 847 & $\begin{array}{l}6600 \pm 80(5666-5380 \mathrm{cal} \mathrm{BC}), 5900 \pm 80(4962 \\
-4553 \mathrm{cal} \mathrm{BC}), 2960 \pm 60(1386-1004 \mathrm{cal} \mathrm{BC})\end{array}$ & Peñalba, 1989 \\
\hline 37 & Berroberria & Urdax & AS (C) & 110 & $\begin{array}{l}9740 \pm 140(9660-8735 \mathrm{cal} \mathrm{BC}), 8860 \pm 100(8263 \\
-7676 \mathrm{cal} \mathrm{BC}), 8800 \pm 80(8212-7612 \mathrm{cal} \mathrm{BC}) \\
8630 \pm 70(7935-7536 \mathrm{cal} \mathrm{BC}) \\
8580 \pm 80(7816-7484 \mathrm{cal} \mathrm{BC}), 8510 \pm 90(7731 \\
-7352 \mathrm{cal} \mathrm{BC}), 8470 \pm 80(7610-7329 \mathrm{cal} \mathrm{BC}) \\
8130 \pm 90(7451-6780 \mathrm{cal} \mathrm{BC}), 7640 \pm 90(6652 \\
-6265 \mathrm{cal} \mathrm{BC}), 2655 \pm 35(985-793 \mathrm{cal} \mathrm{BC})\end{array}$ & Boyer-Klein, 1984 \\
\hline 38 & Padre Areso & Biguezabal & AS (OA) & 900 & $\begin{array}{l}5400 \pm 100(4447-3993 \mathrm{cal} \mathrm{BC}), 3020 \pm 35(1394 \\
-1129 \mathrm{cal} \mathrm{BC}), 1130 \pm 60(731-1019 \mathrm{cal} \mathrm{AD})\end{array}$ & Iriarte et al., 2007/2008 \\
\hline 39 & Quinto Real & Valle de Baigorri & $\mathrm{ND}(\mathrm{P})$ & 910 & $\begin{array}{l}4120 \pm 40(2871-2577 \mathrm{cal} \mathrm{BC}), 3045 \pm 70(1449 \\
-1058 \text { cal BC), } 2645 \pm 45(901-775 \mathrm{cal} \mathrm{BC}) \\
1895 \pm 50(5-237 \mathrm{cal} A D), 1155 \pm 35(775 \\
-969 \mathrm{cal} A D), 290 \pm 40(1784-1795 \mathrm{cal} \mathrm{AD})\end{array}$ & Galop et al., 2004 \\
\hline 40 & Zatoya & Abaurrea Alta & AS (C) & 900 & $\begin{array}{l}8260 \pm 550 \mathrm{BP}(8618-6033 \mathrm{cal} \mathrm{BC}), 8150 \pm 220 \\
(7584-6595 \mathrm{cal} \mathrm{BC}), 6320 \pm 280(5743 \\
-4590 \mathrm{cal} \mathrm{BC})\end{array}$ & Boyer-Klein, 1989 \\
\hline \multicolumn{7}{|c|}{ Transition area } \\
\hline 41 & Ameztutxo & Ilarduia & AS $(\mathrm{OA})$ & 594 & - & Pérez-Díaz 2012 \\
\hline 42 & Arreo & Lantarón & $\mathrm{ND}(\mathrm{L})$ & 655 & $\begin{array}{l}2480 \pm 70(782-414 \text { cal BC), } 1860 \pm 40(65 \\
-243 \text { cal AD), } 1550 \pm 35(420-584 \text { cal AD }) \\
1400 \pm 60(541-767 \text { cal AD), } 1170 \pm 70(688 \\
-992 \text { cal AD) }\end{array}$ & Corella et al., 2013 \\
\hline 43 & Atxa & Vitoria-Gasteiz & AS $(O A)$ & 525 & $\begin{array}{l}2410 \pm 90(792-261 \mathrm{cal} \mathrm{BC}), 2320 \pm 90(755 \\
-177 \mathrm{cal} \mathrm{BC}), 2280 \pm 80(730-111 \mathrm{cal} \mathrm{BC}) \\
2200 \pm 80(397-54 \mathrm{cal} \mathrm{BC}), 2180 \pm 80(394 \\
-46 \mathrm{cal} \mathrm{BC})\end{array}$ & Iriarte, 1994a, 1995b \\
\hline 44 & Berniollo & Subijana-Morillas & AS $(O A)$ & 520 & $\begin{array}{l}9940 \pm 490(10,805-8229 \mathrm{cal} \mathrm{BC}), 4160 \pm 190(3337 \\
-2206 \mathrm{cal} \mathrm{BC}), 3910 \pm 100(2836-2044 \mathrm{cal} \mathrm{BC})\end{array}$ & Isturiz and Sanchez-Goñi, 1990 \\
\hline 45 & Kanpanoste & Vírgala & AS (RS) & 700 & $\begin{array}{l}8200 \pm 70(7451-7059 \mathrm{cal} \mathrm{BC}), 7920 \pm 100(7072 \\
-6534 \mathrm{cal} \mathrm{BC}), 7620 \pm 70(6634-6371 \mathrm{cal} \mathrm{BC})\end{array}$ & Sánchez-Goñi, 2004 \\
\hline 46 & Kanpanoste Goikoa & Vírgala & AS (RS) & 720 & $\begin{array}{l}7860 \pm 330(7528-6095 \mathrm{cal} \mathrm{BC}), 7620 \pm 80(6641 \\
-6266 \mathrm{cal} \mathrm{BC}), 6550 \pm 260(5986-4913 \mathrm{cal} \mathrm{BC}) \\
6360 \pm 70 \mathrm{BP}(5475-5217 \mathrm{cal} \mathrm{BC}) \\
4550 \pm 40(3485-3100 \mathrm{cal} \mathrm{BC}), 4350 \pm 60(3321 \\
-2878 \mathrm{cal} \mathrm{BC}), 4190 \pm 100(3013-2490 \mathrm{cal} \mathrm{BC})\end{array}$ & Iriarte, 1998 \\
\hline 47 & Kukuma & Araia & AS (C) & 715 & $11,550 \pm 130(11,762-11,215$ cal BC $)$ & Isturiz, 1997 \\
\hline 48 & La Peña & Marañón & AS (RS) & 640 & $\begin{array}{l}7890 \pm 120(7065-6491 \mathrm{cal} \mathrm{BC}), 4350 \pm 80(3338 \\
-2765 \mathrm{cal} \mathrm{BC}), 3710 \pm 60(2286-1943 \mathrm{cal} \mathrm{BC}) \\
3610 \pm 60(2140-1775 \mathrm{cal} \mathrm{BC}), 2840 \pm 70(1207 \\
-840 \mathrm{cal} \mathrm{BC})\end{array}$ & López-García, 1991/1992 \\
\hline 49 & Los Castros de Lastra & Caranca & AS (OA) & 830 & $\begin{array}{l}2990 \pm 80(1419-1005 \mathrm{cal} \mathrm{BC}), 2800 \pm 90(1249 \\
-802 \mathrm{cal} \mathrm{BC}), 2760 \pm 90(1193-787 \mathrm{cal} \mathrm{BC}) \\
2750 \pm 90(1192-774 \mathrm{cal} \mathrm{BC}), 2730 \pm 170(1313 \\
-414 \mathrm{cal} \mathrm{BC}), 2720 \pm 80(1112-769 \mathrm{cal} \mathrm{BC}) \\
2680 \pm 100(1116-538 \mathrm{cal} \mathrm{BC}), 2630 \pm 190(1300 \\
-259 \mathrm{cal} \mathrm{BC}), 2580 \pm 80(897-417 \mathrm{cal} \mathrm{BC}) \\
2530 \pm 80(806-413 \mathrm{cal} \mathrm{BC}), 2520 \pm 80(808 \\
-407 \mathrm{cal} \mathrm{BC}), 2300 \pm 80(749-577 \mathrm{cal} \mathrm{BC}) \\
2140 \pm 80(383-0)\end{array}$ & Pérez-Díaz, 2012 \\
\hline 50 & Masparra & Margarita & AS (OA) & 504 & - & Pérez-Díaz and López-Sáez, 2013 \\
\hline 51 & Mendandia & Sáseta & AS (RS) & 720 & $\begin{array}{l}8500 \pm 60(7605-7460 \mathrm{cal} \mathrm{BC}), 7810 \pm 50(6803 \\
-6500 \mathrm{cal} \mathrm{BC}), 7780 \pm 60(6754-6468 \mathrm{cal} \mathrm{BC}) \\
7620 \pm 50(6590-6410 \mathrm{cal} \mathrm{BC}) \\
7210 \pm 45(6211-6004 \mathrm{cal} \mathrm{BC}), 7180 \pm 45(6206 \\
-5933 \mathrm{cal} \mathrm{BC}), 6540 \pm 70(5620-5371 \mathrm{cal} \mathrm{BC}) \\
6440 \pm 40(5478-5330 \mathrm{cal} \mathrm{BC})\end{array}$ & Iriarte, 2006 \\
\hline 52 & Mendizabala & Vitoria-Gasteiz & AS (OA) & 534 & $2860 \pm 35(1187-918 \mathrm{cal} \mathrm{BC})$ & Pérez-Díaz 2012 \\
\hline 53 & Peña Larga & Cripán & AS (RS) & 900 & $\begin{array}{l}6720 \pm 40(5715-5560 \mathrm{cal} \mathrm{BC}), 6150 \pm 230(5524 \\
-4544 \mathrm{cal} \mathrm{BC}), 5830 \pm 110(4977-4451 \mathrm{cal} \mathrm{BC}) \\
5720 \pm 40(4684-4463 \mathrm{cal} \mathrm{BC}), 5010 \pm 40(3944 \\
-3704 \mathrm{cal} \mathrm{BC}), 4890 \pm 50(3787-3536 \mathrm{cal} \mathrm{BC}) \\
4550 \pm 40(3485-3100 \mathrm{cal} \mathrm{BC}), 4470 \pm 160(3633 \\
-2702 \mathrm{cal} \mathrm{BC}), 4040 \pm 40(2838-2469 \mathrm{cal} \mathrm{BC})\end{array}$ & Iriarte, 1997a, Pérez-Díaz 2012 \\
\hline 54 & Peña Parda & Laguardia & AS (RS) & 975 & - & Pérez-Díaz et al., 2007 \\
\hline 55 & San Cristóbal & Laguardia & AS (RS) & 1037 & $\begin{array}{l}5100 \pm 30(3968-3800 \mathrm{cal} \mathrm{BC}), 4980 \pm 30(3911 \\
-3663 \mathrm{cal} \mathrm{BC}), 4930 \pm 30(3771-3651 \mathrm{cal} \mathrm{BC}) \\
4470+40(3345-3022 \mathrm{cal} \mathrm{BC}) \\
4290 \pm 40(3022-2780 \mathrm{cal} \mathrm{BC}), 4170 \pm 40(2886 \\
-2628 \mathrm{cal} \mathrm{BC}), 4100 \pm 40(2870-2498 \mathrm{cal} \mathrm{BC}) \\
4080 \pm 40(2862-2489 \mathrm{cal} \mathrm{BC}), 4030 \pm 40(2835 \\
-2468 \mathrm{cal} \mathrm{BC}), 3990 \pm 40(2620-2350 \mathrm{cal} \mathrm{BC})\end{array}$ & Pérez-Díaz, 2012 \\
\hline
\end{tabular}




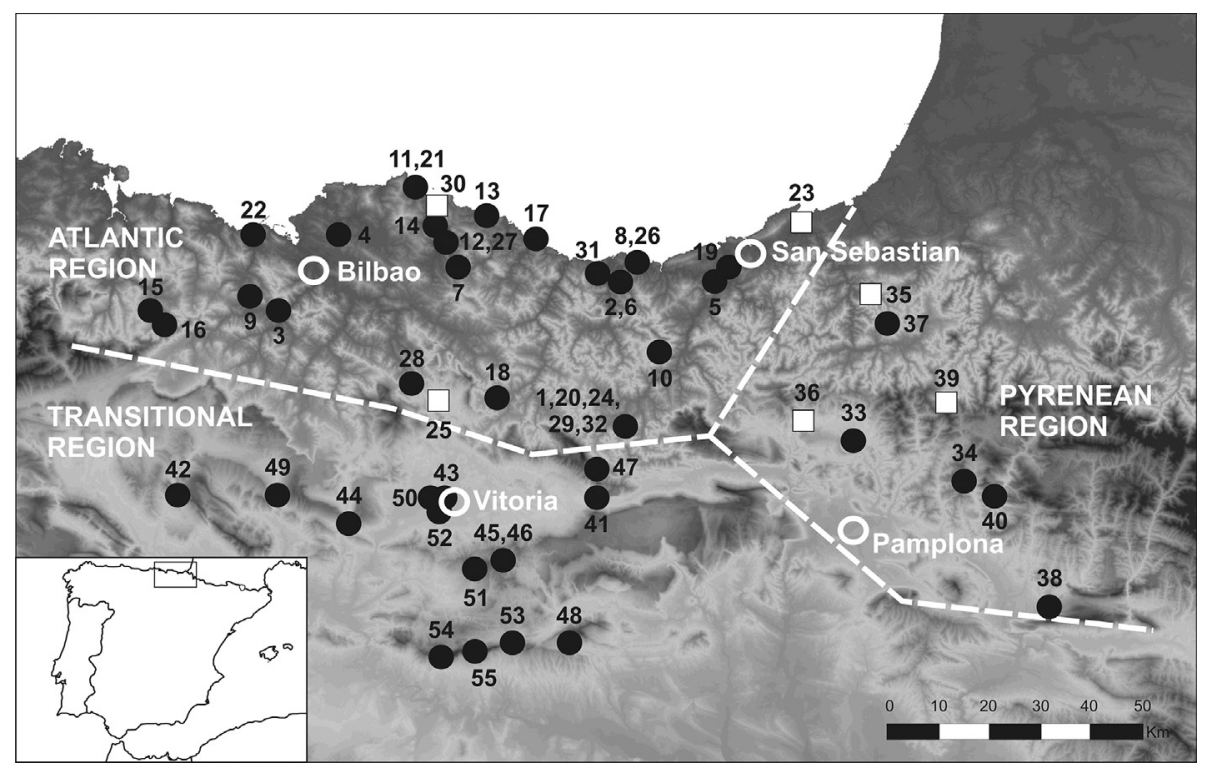

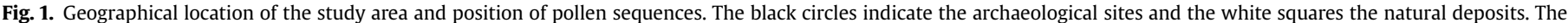
white circle indicates the mains town in this area. Sequence numbers refer to Table 1.

These determinations have been calibrated with the Calib 7.0 programme at $2 \sigma$ (95.4\% probability) and are given in cal BC or cal $\mathrm{AD}$. In those cases where no radiocarbon dates are available, as at some archaeological sites, it has been used the chronology proposed by archaeologists, and is therefore based on archaeological data.

With the aim of describing the mid-late-Holocene vegetation history, we present a new palynological study of the peat bog of Atxuri, in the Pyrenean area (Maya de Baztán, Navarre), which complements the study of Peñalba (1989) by adding more radiocarbon dates and better sampling resolution. In this new analysis, a total of $235 \mathrm{~cm}$ core was retrieved using a Russian peat sampler
(GYK type, $50 \mathrm{~cm}$ length; $5 \mathrm{~cm}$ in diameter). Chronology was based on four Accelerator Mass Spectrometry (AMS) radiocarbon dates (Table 2). These dates were used to build an age-depth model by linear interpolation taking into account the maximum probability intervals at 2 sigma ranges. Subsamples for pollen analysis consisted of $1 \mathrm{~cm}^{3}$ cubes taken at $5 \mathrm{~cm}$ intervals, so a total of 47 samples were analysed. Pollen preparation followed standard methods using treatment with $\mathrm{HCL}, 10 \% \mathrm{KOH}, \mathrm{HF}$, acetolysis and final mounting in glycerine. 450 terrestrial pollen grains were counted in each sample. Cyperaceae, Calluna, aquatics and spores were excluded from the pollen sum to avoid over-representation by local taxa. All pollen types are defined according to Faegri and

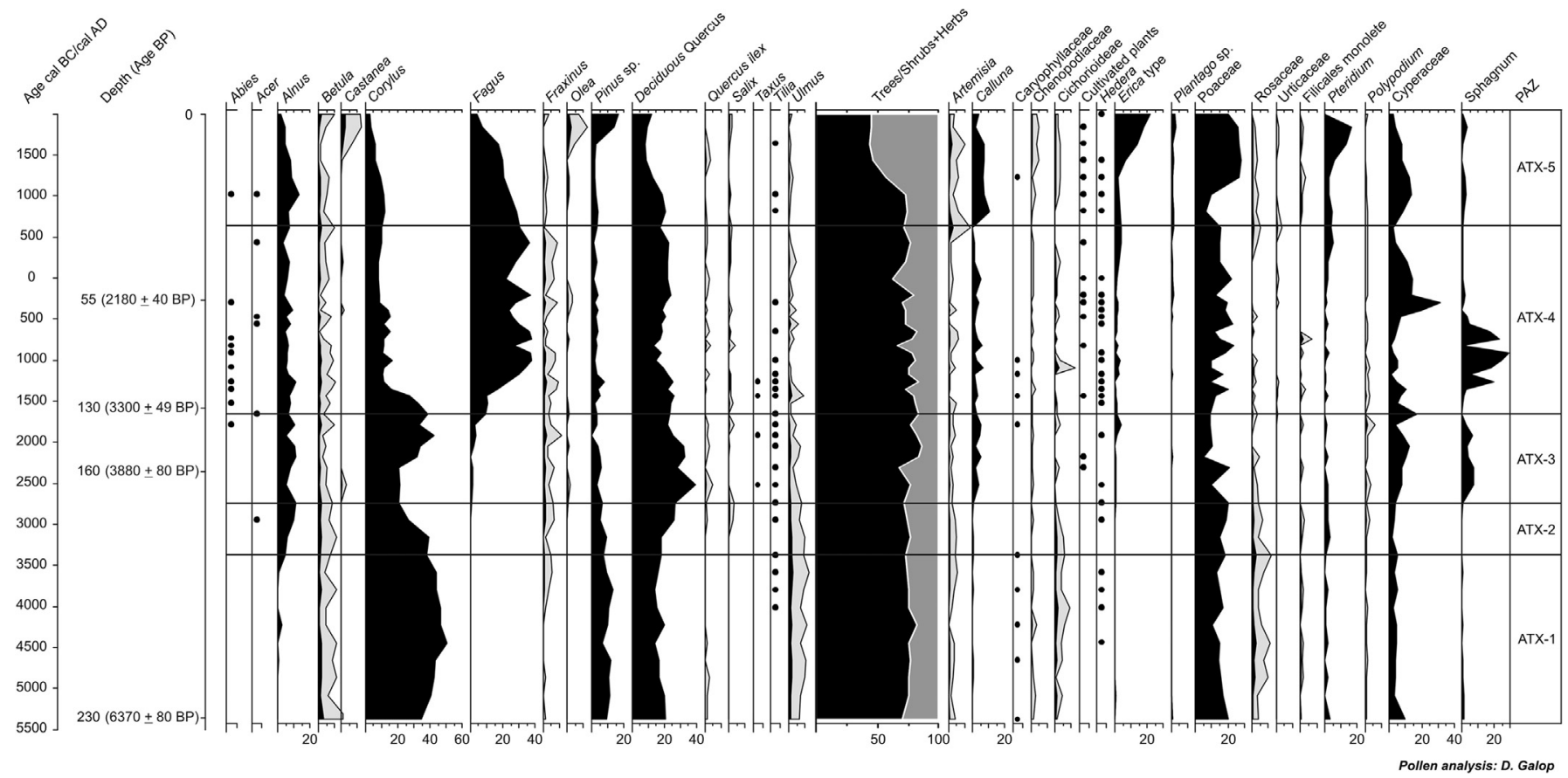

Fig. 2. Palynological diagram from the peat bog of Atxuri. 
Iversen (1989), although some identification required the use of a pollen atlas (Reille, 1992; Beug, 2004). The palynological diagram (Fig. 2) was produced using the Tilia 2.0 and TGView programs (Grimm, 1992, 2004). absolute dates. But the distribution of those radiocarbon dates is not uniform, and we have sites with more than 10 radiocarbon dates (Gastiburu, Abauntz, Berroberria, Los Castros de Lastra, Peña Larga, San Cristóbal) and others with no one (Berreaga, Kosnoaga, Sustrigi, Ameztutxo, Peña Parda). For this reason, we have been

Table 2

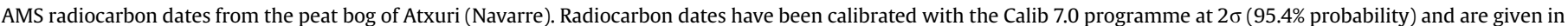
cal BC.

\begin{tabular}{|c|c|c|c|c|c|c|}
\hline Sample & Material & Depth interval & Lab code & Age uncalibrated BP & Age cal $\mathrm{BC}(2 \sigma$ range probability area) & Medium age cal $\mathrm{BC}$ \\
\hline Atxuri-55 & Peat & $54-55$ & BETA-156993 & $2180 \pm 40$ & $371-113$ & 265 \\
\hline Atxuri-130 & Peat & $129-130$ & BETA-156995 & $3300 \pm 49$ & $1683-1499$ & 1577 \\
\hline Atxuri-160 & Peat & $159-160$ & BETA-156994 & $3880 \pm 80$ & $2470-2210$ & 2368 \\
\hline Atxuri-230 & Peat & $229-230$ & GIFA-99149 & $6370 \pm 80$ & $5491-5081$ & 5355 \\
\hline
\end{tabular}

\section{Results and discussion}

\subsection{Pollen zones of the Atxuri pollen diagram}

The new pollen percentage diagram of the Atxuri peat bog was divided into five main biostratigraphic zones (Fig. 2) using CONISS, and provides insight into the vegetation history and the human pressure of the Pyrenean region from $\mathrm{ca}$. $5500 \mathrm{cal} \mathrm{BC}$ to the present day. The first period (PAZ ATX-1, 235-185 cm depth, ca. 5568-3434 cal BC) is dominated by mesophylous woodland, with Corylus and deciduous Quercus as main taxa, and to a lesser extent Betula and Ulmus. Among herbs, Poaceae reach highest values (20\%). The PAZ ATX-2 (185-170 cm depth, ca. 3434-2795 cal BC) shows the rise of deciduous Quercus, Alnus, and Fraxinus, and some decline in Corylus and Pinus. Poaceae is also the main herbaceous taxa represented in the diagram. At the PAZ ATX-3 (170-135 cm depth, ca. 2795-1709 cal BC) the vegetation is dominated by mesophylous woodland. At the beginning of this PAZ, deciduous Quercus continues its upward trend, reaching the maximum values of the whole sequence (39\%). At this moment Corylus start to rise, to become again in the dominant tree taxa. The diagram shows the first appearences of Fagus, but in low values, the rise of Calluna and Sphagnum, and the first evidences of cultivated plants. At the PAZ ATX-4 (135-40 cm depth, ca. 1709-738 cal BC) the most important event is the spread of Fagus, reaching 39\% and being, from this moment, the dominant woodland. Anthropogenic pollen indicators, such as Plantago, Urticaceae, Chenopodiaceae, and cultivated plants are more abundant at this time. Finally, the PAZ ATX-5 (40-0 cm depth, ca. 738-present day) shows a drastic drop of Fagus. The rest of the mesophylous woodland also shows a downward trend. At the end of the sequence Pinus increases its values. Poaceae, Calluna and Erica type, together with Pteridium, increases significantly their presence in the vicinity of the peat bog, where anthropogenic pollen indicators and cultivated plants are also evident.

\subsection{Vegetation history and human impact during the Holocene}

This section is organised according to chrono-cultural periods, giving an overall view of the composition of the vegetation and the anthropic impact during the Holocene on the Spanish side of the Western Pyrenees. For this purpose we have taken into account the new data from the peat bog of Atxuri and the rest of the palynological studies published for the Pyrenees, the Atlantic area and the Transitional region, both from archaeological sites and natural ones. As we mentioned, we have considered all the studies chronologically situated between the Epipaleolithic-Mesolithic and the Iron Age, and its radiocarbon dates. We have collected a total of 219 very cautious when correlating palynological data from diferent sites.

\subsubsection{Epipalaeolithic-Mesolithic. The environment background to} the first Holocene cultures (ca. 9500-5500 cal BC)

The end of the Late Glacial and the arrival of the Holocene involved the end of Upper Palaeolithic cultures (Magdalenian), and was the starting point of new ways of life adapted to more benign climate conditions and a noticeably different flora composition. From the palaeoenvironmental viewpoint, one of the most important features of the early Holocene is a significant climatic amelioration, with a steady rise in both the temperature and precipitations (Bradley, 1999; Burroughs, 2005; Carrión et al., 2010; Muñoz-Sobrino et al., 2013).

The climate (temperature and precipitations) is, after all, one of the factors determining the vegetation communities anywhere. In the case of south-west Europe, the climate amelioration at the start of the Holocene favoured the expansion of arboreal taxa, leading to a significant reduction in the areas occupied by steppe communities, which were characteristic of the Late Glacial period (Duplessy et al., 1981; Ruddiman and McIntyre, 1981; Bard et al., 1987; Naughton et al., 2007; Fletcher et al., 2010; Jalut et al., 2010; Sadori, 2013).

Several palaeoenvironmental sequences have been documented in the Atlantic part of the region for this period. The extensive tree cover, dominated by deciduous taxa (deciduous oaks, hazel and elm) and accompanied by scots pine, is the most important trait they display. These coastal deposits also document other thermophilous elements like evergreen oak $(Q$. ilex) and Olea. Both species, together with others that are less abundant in the palaeobotanical record, like Arbutus unedo, Laurus nobilis and Rhamnus, could have formed part of cantabric holm oak-type communities (Table 3). Dispersed formations are still found on the northern Spanish coast, surviving in areas with poor dry soils, normally limestone areas where little water is retained. It is a relict community that continues to survive owing to the mild climate on the Atlantic coast (Bueno and Fernández, 1991; Meaza, 1991), and which has been documented in the palaeobotanical record since at least the Late Glacial period (Ramil et al., 1998). It is evident between ca. 8300 and $5300 \mathrm{cal}$ BC at sites like Urdaibai (Iriarte et al., 2006), Playaundi (Sanchez-Goñi, 1996), Kobeaga II (Iriarte, 2000) and Pareko Landa (Iriarte et al., 2007/2008). At sites in inland valleys in the Atlantic zone the vegetation dynamic is similar, with the difference that further from the coast, the marine influence is reduced and thermophilic-sclerophilic elements like holm oak are scarcer. The predominance of deciduous formations is shown above all by the spread of hazel copses in the pollen record, together with other deciduous species like alder, birch, deciduous Quercus, linden 
and wallnut, as shown by the studies carried out at sites like Arenaza (Isturiz and Sanchez-Goñi, 1990), Ekain (Dupré, 1984), Urtiaga (Sanchez-Goñi, 1993) and Sustrigi (Iriarte et al., 2007/2008), between ca. 10,600 and $7500 \mathrm{cal} \mathrm{BC}$. The same trend is recorded in some nearby marine sequences, where deciduous woodlands were dominant in the Early Holocene (Naughton et al., 2007; da Silva, 2012). mixed deciduous woodland (birch, alder, deciduous Quercus, ash, willow, poplar), as well as some pines and, in Padre Areso, holm oaks (Q. ilex type), owing to its more southern location (Table 3 ).

In a more inland area, in the climate Transition zone, several archaeological sites are known in a relatively small radius (SubMediterranean valleys), all of the same chronology. As may be expected, they all reflect a very similar environmental dynamic in

Table 3

Summary of the main vegetation features of the Holocene in the Western Pyrenean Region.

\begin{tabular}{|c|c|}
\hline Chronocultural phases & Main vegetation features \\
\hline \multicolumn{2}{|c|}{ Epipaleolithic-Mesolithic (ca. 9500-5500 cal BC) } \\
\hline Pyrenees & $\begin{array}{l}\text { - In the high altitudes preponderance of conifer formations (Pinus sylvestris) } \\
\text { - In lower altitudes dominance of deciduous woodlands (Corylus, Betula, Alnus, deciduous Quercus, Fraxinus, Salix, Populus). }\end{array}$ \\
\hline Athlantic area & $\begin{array}{l}\text { - Spread of deciduous forests (deciduous Quercus, Corylus, Ulmus, Alnus, Betula, Tilia). } \\
\text { - Lou presence of Pinus sylvestris. } \\
\text { - In the coastal area presence of thermophylous copses, cantabric holm oak-type communities with Quercus ilex, Olea, Arbutus unedo, } \\
\text { Laurus nobilis and Rhamnus. }\end{array}$ \\
\hline Transition area & $\begin{array}{l}\text { - Dominance of deciduous woodlands, likely shaping mixed forest (Corylus, Betula, Alnus, deciduous Quercus, Fraxinus, Salix, Populus). } \\
\text { - The low representation of Pine (Pinus sylvestris }<10 \% \text { ) indicates its presence at a regional scale. }\end{array}$ \\
\hline \multicolumn{2}{|c|}{ Early Neolithic (ca. 5500-4500 cal BC) } \\
\hline Pyrenees & $\begin{array}{l}\text { - Predominance of deciduous woodlands (Corylus, Betula, deciduous Quercus, Tilia, Alnus, Ulmus) and pines (Pinus sp.) } \\
\text { - First emergence of anthropic palynomorphs (Plantago sp). } \\
\text { - Increasing presence of shrubs. }\end{array}$ \\
\hline Athlantic area & $\begin{array}{l}\text { - Predominance of deciduous woodlands (deciduous Quercus, Corylus, Ulmus, Alnus, Betula and Tilia). } \\
\text { - First emergence of anthropic palynomorphs (Plantago sp). } \\
\text { - First evidences of cultivated plants (cereal pollen and cultivated seeds). }\end{array}$ \\
\hline Transition area & $\begin{array}{l}\text { - Predominance of deciduous woodlans (Corylus, deciduous Quercus, Ulmus, Alnus). } \\
\text { - Increasing open areas. } \\
\text { - Emergence of pastures of anthropogenic origin (Chenopodiaceae, Urtica dioica type, Plantago lanceolata, Sporormiella sp. } \\
\text { and Sordaria sp.) }\end{array}$ \\
\hline \multicolumn{2}{|c|}{ Middle-Late Neolithic and Copper Age (ca. $4500-2200$ cal BC) } \\
\hline Pyrenees & $\begin{array}{l}\text { - Predominance of mesophylous forests wit Corylus, deciduous Quercus, Betula, Ulmus, Alnus, Tilia and Fraxinus). } \\
\text { - Regression in values of arboral pollen. } \\
\text { - Emergence of crop fields (cereal pollen grains). }\end{array}$ \\
\hline Athlantic area & $\begin{array}{l}\text { - Prevalence of deciduous arboreal vegetation (Corylus, deciduous Quercus, Ulmus, Alnus, Fraxinus). } \\
\text { - Development of open areas. } \\
\text { - Emergence of crop fields (cereal pollen and cultivated seeds). }\end{array}$ \\
\hline Transition area & $\begin{array}{l}\text { - Dominance of deciduous forests (Corylus, deciduous Quercus, Ulmus, Alnus, and Fraxinus). } \\
\text { - From the Chalcolithic increase of evergreen forests in the southern sector (Quercus ilex, Buxus). } \\
\text { - Regression in values of arboral pollen. } \\
\text { - Cereal pollen }>3 \% \text { and cultivated seeds. }\end{array}$ \\
\hline \multicolumn{2}{|c|}{ Bronze Age and Iron Age (ca. $2200-200$ cal BC) } \\
\hline Pyrenees & $\begin{array}{l}\text { - Presence of deciduous forests (deciduous Quercus, Corylus, Alnus, Betula) and conifers (Pinus sylvestris). } \\
\text { - Spread of Fagus. } \\
\text { - Agro-pastoral activities. }\end{array}$ \\
\hline Athlantic area & $\begin{array}{l}\text { - Dominance of deciduous forests (deciduous Quercus, Corylus, Tilia, Fraxinus, Ulmus). } \\
\text { - Spread of Fagus. } \\
\text { - Crop fields and anthropogenic pastures. }\end{array}$ \\
\hline Transition area & $\begin{array}{l}\text { - Presence of deciduous forests and develpoment of evergreen forest in the southernmost area (evergreen Quercus, } \\
\text { Pinus sylvestris, Buxus). } \\
\text { - Spread of Fagus. } \\
\text { - Crop fields and anthropogenic pastures }\end{array}$ \\
\hline
\end{tabular}

In the Pyrenees, palynological studies of both archaeological deposits and peat bogs display the characteristic arboreal colonisation in the early Holocene. However, in this area, pine forests predominate, together with smaller deciduous stands formed by hazel, birch, alder and deciduous Quercus. This is seen at the archaeological sites of Abauntz, Zatoya and Berroberría (LópezGarcía, 1982; Boyer-Klein, 1984) between 10,000 and 6300 cal BC. The montane environment clearly explains the preponderance of conifer formations (pine forests) over deciduous woodlands, which are of secondary importance at the start of the Holocene. In other deposits located at lower altitudes, such as the sites of Aizpea and Padre Areso, once more deciduous woodland is the main vegetation type. In this case, hazel is the main element in the Mesolithic forest during the whole seventh millennium cal BC (Iriarte, 2001; Iriarte et al., 2007/2008). It is accompanied by other typical trees in which the area was fully occupied by deciduous woodland, a mixed forest where hazel predominated over deciduous oak, birch, lime, yew and willows. Pine is present in the record but with low percentages $(<10 \%)$, possibly indicating its presence at a regional scale. This is seen in the palynological studies at Mendandia (Iriarte, 2006), Kanpanoste (Sánchez-Goñi, 2004) and Kanpanoste Goikoa (Iriarte, 1998) from ca. 6800 to $6000 \mathrm{cal} \mathrm{BC}$.

\subsubsection{Early Neolithic (ca. 5500-4500 cal BC). First evidence of farming}

In the sixth millennium cal BC, a new archaeological reality can be recognised in the Iberian Peninsula: the Neolithic technocomplex. It appears in a cultural process, within which a series of transformations resulted in the Mesolithic way of life (huntergatherers) changing to another situation in which food was 
produced by agriculture and animal husbandry. The new economic practices also led to a series of social transformations which are equally reflected in the vegetation, mainly because of the need for open spaces for the new productive activities.

The Western Pyrenees has traditionally been considered a marginal area as regards the adoption of Neolithic ways of life, supposedly with a delay in the arrival of the first Neolithic evidence (Zapata et al., 2004; Zapata and Peña-Chocarro, 2012). However, several research projects in the last decade have questioned this view, as they have documented certain novelties associated with the Neolithic technocomplex dated in the sixth millennium cal BC at such sites as the rock-shelter of Peña Larga (5700-5500 cal BC) (Fernández-Eraso, 2007/2008), Cueva de Marizulo (5500-5200 cal BC) (Alday and Mujika, 1999), Atxoste (5300-5000 cal BC) (Alday et al., 2012), Cueva de Arenaza (5200-4800 cal BC) (Arias and Altuna, 1999) and the open-air settlement of Herriko Barra (5200-4700 cal BC) (Iriarte et al., 2004). One particularity of the Neolithic in this area is the clear existence of two types of archaeological sites in terms of the inhabitants' forms of subsistence. At one type, intense use of wild resources has been documented (Abauntz, Aizpea, Herriko Barra, Kanpanoste Goikoa, Pico Ramos, Zatoya), whereas the other type exhibits marked evidence of pastoral or agricultural activity (Arenaza, Kobaederra, Peña Larga). This reveals a wide range of situations, possibly derived from the origin and evolution of the early Neolithic in the region.

In the Atlantic zone, several palaeoenvironmental studies have noted the first evidence of anthropisation of the landscape in the late sixth millennium and during the fifth millennium cal BC, such as the deposits of Pico Ramos ca. 4800-4500 cal BC (Zapata, 2002) and Pareko Landa (Iriarte et al., 2007/2008), where deforestation was incipient. However, in these deposits no evidence of farming practices has been documented, unlike at other nearby sites, such as Herriko Barra ca. 5200-4700 cal BC (Iriarte et al., 2004), where cereal pollen was identified. This is one of the earliest evidence of the development of agriculture on the northern coast of Iberia, at a site where neither pottery nor domestic animals were recorded and which, therefore, appears to have specialised in the use of wild resources in a diet complemented by cereals. Other palaeobotanical remains of cereals, in this case grains, were identified at some neighbouring sites, like Kobaederra ca. 4700-4300 cal BC (Zapata, 2002). Unlike at the coastal sites of Pico Ramos and Herriko Barra, the identification of domestic fauna at Kobaederra seems to indicate an economic focus on domestic resources, especially livestock but also agriculture.

In the Pyrenees, studies at such sites as Abauntz (López-García, 1982), Zatoya (Boyer-Klein, 1989) and Aizpea (Iriarte, 2001) suggest the predominance of deciduous woodland during the early Neolithic (hazel, birch, deciduous Quercus, linden, alder). The same trend is documented in some peat bogs (Table 3 ). In the case of the new palynological study of Atxuri presented here, the diagram show at the PAZ ATX-1 ( $\mathrm{ca}$. 5568-3434 cal BC) a predominance of hazel, reaching $50 \%$ of terrestrial pollen, and other deciduous woods, with Quercus, birch and elm as main components, together with pines (Fig. 2). Although discreet, some indicators of incipient anthropisation have been detected in this area, such as preponderance of hazel, and a residual presence of anthropic palynomorphs and heaths (López-Sáez et al., 2007/2008). However, no farming practices have been detected in any of these records, which can undoubtedly be related to the continuation of Mesolithic ways of life in these mountain environments, where hunting and gathering took priority. Some evidence of anthropisation is also recognisable in peat bogs. At Belate, in the first half of the fifth millennium cal BC (ca. 5000-4500 cal BC), heliophilous and anthropic taxa and shrubs proliferated, attesting some disturbance to the natural woodland vegetation (Peñalba, 1989).

In the climate Transition zone, the oldest references correspond to the site of Mendandia. Palynological data (Iriarte, 2006) document a steep decline in arboreal pollen in the central part of the sixth millennium cal BC ( $c a .5700-5300 \mathrm{cal} \mathrm{BC})$ in comparison with the Mesolithic, as it only reaches a percentage of about $9 \%$. Hazel is still the most common tree (Table 3), together with other deciduous species, like oaks, lime and others found in very small proportions (alder, walnut and elm). This significant decline in the

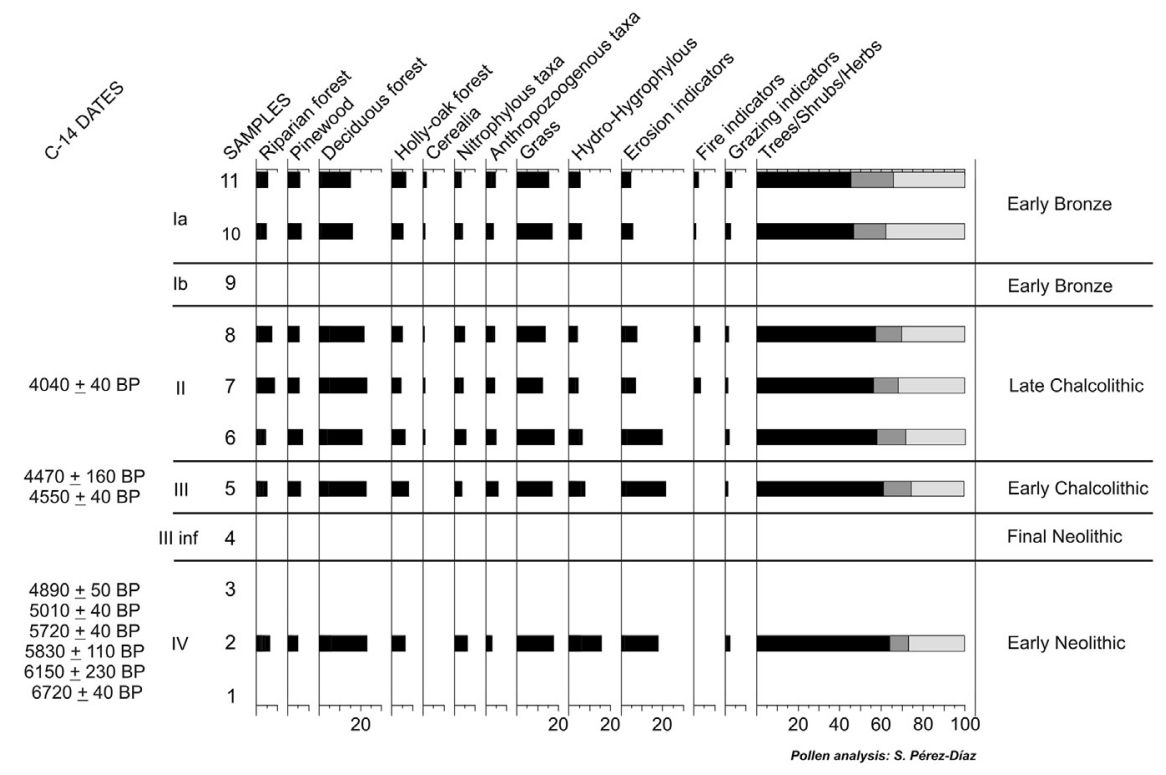

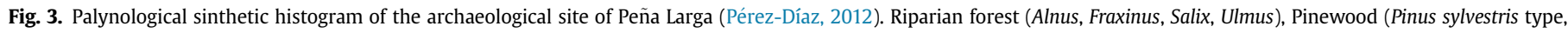

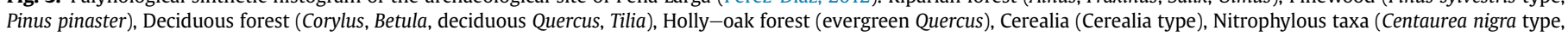

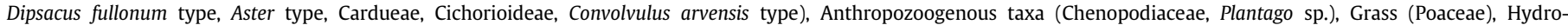

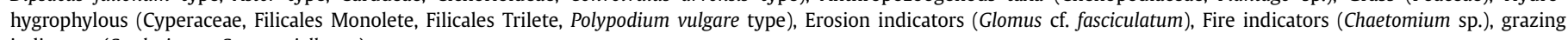
indicators (Sordaria sp., Sporormiella sp.). 
representation of forest masses is undoubtedly connected with human activity, as attested by a large increase in synanthropic pollen taxa, above all Compositae liguliflorae, and to a lesser extent Dipsacaceae and Compositae tubuliflorae, which often accompany human presence.

In the southern mountains, in Sierra de Cantabria, the early Neolithic in the deposit of Peña Larga, ca. 5700-4500 cal BC (Fernández-Eraso, 2007/2008) is characterised by the existence of deciduous woodland in the surroundings of the rock-shelter, in which hazel was the most common species, together with deciduous Quercus, birch, linden, etc. (Fig. 3). Economic practices appear to have been focused on pastoralism (Pérez-Díaz, 2012), according to the palynological evidence, with the characteristic vegetation of nitrified soils (anthropozoogenous pastures with Chenopodiaceae, Urtica dioica type, Plantago lanceolata), as well as coprophilous fungi (Sporormiella sp. and Sordaria sp.) (van Geel, 1976, 1978, 2006; van Geel et al., 1983, 2003; López-Sáez et al., 2000). These conclusions are also supported by the archaeozoological study which identified remains of domestic cattle, ovicaprines and pigs, as well as some wild animals (Castaños, 1997). The first results of DNA analysis of osseous remains point in the same direction (Fernández Eraso, 2010). In the immediate vicinity, the rock-shelter of Los Husos I has yielded cereal pollen in ca. 5200-4800 cal BC (Fernández-Eraso, 2007/2008).

\subsubsection{Middle-Late Neolithic and Copper age (ca.}

\section{0-2200 cal BC). Consolidation of the producing economy}

The appearance of a broad series of novelties associated with the Neolithic technocomplex, from the sixth millennium cal BC onwards, marked the start of change in the ways of life of the communities that had lived in the region until then. These changes affected vital aspects of human society, such as the structuring of space, settlement patterns, social relationships, funerary behaviour, and so on. They become particularly clear in the Middle-Late Neolithic (ca. 4500-3200 cal BC) and the Chalcolithic (ca. 3200-2200 cal BC). Additionally, they left an unquestionable impact on the vegetation.

In the Athlantic zone, palynological studies show the prevalence of deciduous arboreal vegetation, typical of temperate and humid conditions (Table 3). Mixed forests predominated, above all with hazel and oak, together with Rosaceae, elm, ash, alder, etc. However, this woodland displayed clear evidence of anthropisation, mainly in the form of human deforestation, with the presence of nitrophilous herbaceous taxa between ca. 4200 and $2500 \mathrm{cal} \mathrm{BC}$, in Katillotxu (Iriarte, 2007/2009) and Pico Ramos (Iriarte, 1994b). The latter site also yielded data about the adoption of agriculture in this part of the coastal strip, as the carpological study cites remains of Hordeum vulgare (together with wild plants) in the late fifth and early fourth millennia cal BC (4229-3798 cal BC) (Zapata, 2002). Deforestation is generally recorded in most of the archaeological deposits, but is less apparent in natural deposits, like in Saldropo (Peñalba, 1989). In these cases, the scant alteration of the vegetation due to anthropic action may be explained by the absence of archaeological sites in their vicinity, which meant they were relatively unaffected by prehistoric activity.

In the Pyrenean zone, several deposits are known. The same general pattern is seen in them all: the dominance of mesophylous woods (hazel, oak). In the case of Atxuri (last part of PAZ ATX-1, PAZ ATX-2 and beginning of PAZ ATX-3), other deciduous taxa appear at this moment, such as alder and ash, beginning their continuous presence in the sequence (Fig. 2). Diagrams also show the interaction of human communities with all Pyrenean ecosystems, on a much larger scale than in the Early Neolithic. Some very clear signs of anthropisation have been noted in all the pollen sequences. Accordingly, the earliest evidence of agriculture in the Navarran
Pyrenees dates back to the fourth millennium cal BC, as cereal pollen has been identified ca. 4000-3500 cal BC in Quinto Real (Galop et al., 2001), ca. 3250 cal BC in Artxilondo (Galop, 2005), and ca. 2300 cal BC in Atxuri.

In the Transition zone, deposits with palynological studies reflect the vegetation consisting of deciduous woodland, dominated by hazel and deciduous Quercus, together a significant percentage of riparian vegetation (elm, alder, ash), which indicates a high level of humidity. However, this vegetation was noticeably affected by anthropic deforestation already begun in the Early Neolithic (Table 3). The driving force behind this process of deforestation was farming activity. In this period, most deposits have yielded cereal pollen in percentages of over $3 \%$, which is the value usually taken as a sign of crops being grown in the immediate surroundings of the deposit (Diot, 1992; López-Sáez and LópezMerino, 2005). In the same way, the diagrams reflect several indicators of livestock in the area around the site. As well as nitrophilous herbaceous communities favoured by the presence of animals, a non-pollen micro-fossil of coprophile ecology (Sordaria sp.) has been recorded, a good indicator of livestock in situ (van Geel et al., 1983, 2003). In Sierra de Cantabria, a large number of archaeological sites (Peña Larga, San Cristóbal, Los Husos I and Los Husos II) all show that in the Late Neolithic, the predominant vegetation was still temperate and humid woodland, with deciduous trees like hazel, birch, oak (possibly Portuguese oak) and lime above all, forming a mixed deciduous forest. However, from the climate viewpoint, certain change to more arid conditions is shown in the Chalcolithic by plant species better adapted to warm dry climates, such as box, and a certain preponderance of holm oak formations (Fig. 3). This intense vegetation change was forced by the farming economy. During the Chalcolithic, agriculture became widespread across the region, after the first introductory phase. In several deposits with earlier levels, this seems to be the moment when agriculture developed. Another economic activity visible in the palynological record is animal husbandry. The identification of anthropozoogenic flora, forming part of pastures grazed by livestock, the presence of coprophilous fungi, micromorphological evidence of accumulations of dung, and archaeozoological data draw a picture in which pastoralism was one of the main activities of Middle-Late Neolithic and Chalcolithic communities (Pérez-Díaz, 2012).

\subsubsection{Bronze Age and Iron Age (ca. 2200-200 cal BC). The rise of complex societies}

Our understanding of the last prehistoric societies, defined in Europe as Bronze Age and Iron Age communities, has advanced a great deal in recent decades, with interesting changes from social, cultural and economic perspectives identified (Fernández-Eraso et al., 2009; Sesma et al., 2009). These changes indicate growing socioeconomic complexity, and are reflected clearly in the vegetation (Carozza et al., 2005; Pérez-Díaz and López-Sáez, 2012).

In the Atlantic zone, numerous deposits of this time are known, of various kinds including caves, rock-shelters, open-air sites and megalithic monuments, as well as natural deposits. They all exhibit the predominance of woodland consisting mainly of deciduous Quercus, hazel, linden, ash and elm, as well as the start of the beech expansion (Table 3). These forests display a high level of anthropic alteration. This is most evident in studies carried out at archaeological sites and less so in natural deposits. The palynological record from Saldropo peat bog, in a transitional biogeographic environment between the Atlantic and Mediterranean sides of the watershed, ca. 2200-1700, reflects characteristics noticeably different from those documented at archaeological sites (Peñalba, 1989). Whereas in the latter the main trait is intense anthropisation and the preponderance of vegetation with an anthropic origin, at 


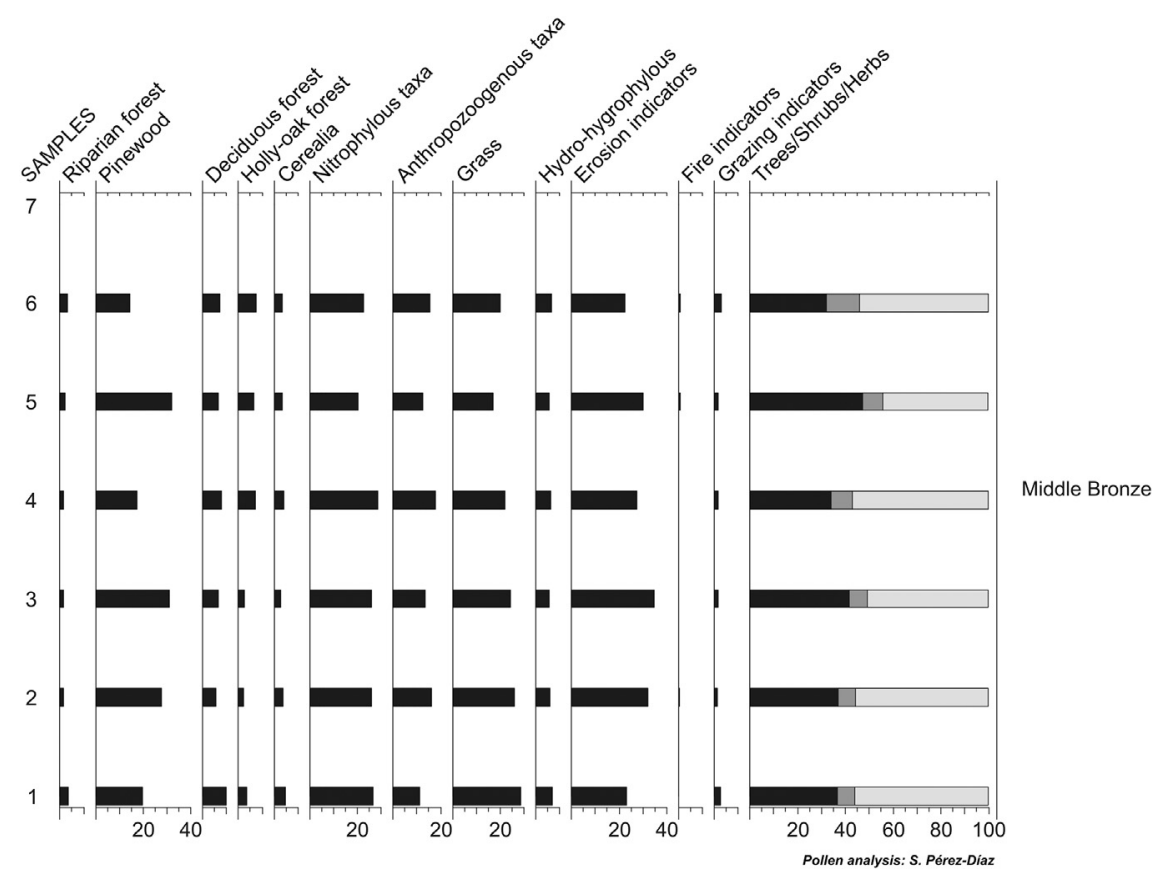

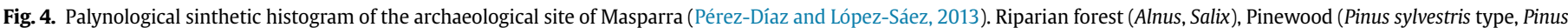

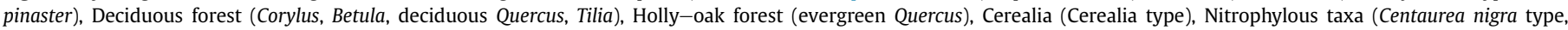

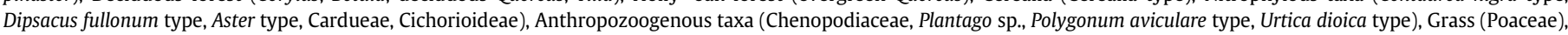

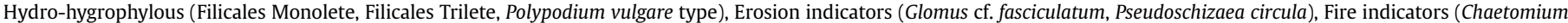
sp.), Grazing indicators (Sordaria sp., Sporormiella sp.).

Saldropo hardly any signs of alteration to the vegetation can be detected. Arboreal cover is important, mainly of deciduous taxa like Quercus and Corylus. The start of the beech expansion is dated at the same time. Similarly, the scarcity of synanthropic elements supports the hypothesis of little human activity in that area.

In the Pyrenees, some deposits are known that cover the last two millennia cal BC. In the cave of Zatoya, the palynological study (Boyer-Klein, 1989) reflected an increase in the representation of pine forests. The vegetation inferred from palynological studies of the peat bogs at Belate (Peñalba, 1989), Atxuri (Fig. 2) and Quinto Real (Galop et al., 2001, 2004) show a similar general dynamic. In the case of Atxuti, presented herein, the diagram shows the development of a mesophylous forest, as previously, dominated by deciduous Quercus and hazel. At the same time, the expansion of beech woods is identified; from ca. 2500 cal BC it detects its continuous presence in the environment and from $\mathrm{ca} .1700 \mathrm{cal} \mathrm{BC} \mathrm{a}$ drastic increases. From this moment beech woods becomes the dominant forest. Certain anthropic presence is detected by the presence of cuitivated plants and nitrophilous communities (Fig. 2).

In the climate Transition zone, tree cover is generally reduced in the surroundings of human settlements and consists mainly of deciduous elements, although in the southernmost areas the advance of herbaceous formations better adapted to dry environments can be detected, in addition to the predominance of pine and holm oak among the trees and box among the bushes (Table 3 ). Farming activity seems to be the driving force behind the intensification of anthropic influences, which is seen in pollen diagrams in the existence of areas with no arboreal vegetation. Practically all the settlements with palynological studies display high levels of cereal pollen, which indicates the relative proximity of agricultural land. In the same way, the identification of herbaceous communities typical of pastures, together with the presence of ascospores of coprophilous fungi, attest the extent of livestock farming and environmental pressure (Fig. 4). This is very clear both in valley sites like Ameztutxo, Masparra, Mendizabala and Los Castros de Lastra, and in deposits in mountain areas, like those at over $900 \mathrm{~m}$ altitude in Sierra de Cantabria (Peña Larga, Peña Parda, San Cristóbal) (Fig. 3).

\section{Conclusions}

The evolution of the landscape during the Holocene in the Western Pyrenees is the result of the interaction of many factors, giving as final result the current landscape configuration. Among these factors we must mention the increasing human activity, especially evident from the first moments of the Neolithic. Moreover, the climatic evolution in this environment has contributed in the evolution of plant communities.

The combination of archaeobotanical studies, specially palynological, in both archaeological sites and natural deposits is a very interesting tool for the reconstrution of vegetation history and the dynamics of anthropisation both spatially and temporally, particularly the development of farming activity (agriculture and pastoralism) and their impact on the environment (deforestation, erosion, fires, etc.).

After the Late Glacial period, characterised by cold and dry conditions, a more benign climate developed in the early Holocene, with increasing humidity and higher temperatures. These new conditions favoured arboreal expansion, and consequently a reduction in the area occupied by the steppe herbaceous communities. The predominant vegetation type in the early Holocene was mixed woodland with deciduous species like hazel, oak, birch, alder, lime, etc., better adapted to the new environmental conditions. Pine forests have also been recorded, especially in high mountain areas of the Pyrenees and more continental conditions in the south of the region.

The first changes associated with the new cultural technocomplex of the Neolithic are seen in the Western Pyrenees at an 
early date, in the late sixth millennium cal BC. At that time, palynological studies have documented animal domestication (presence of ruderal and nitrophilous vegetation and coprophilous fungi) and agriculture (cereals) in several deposits. The new farming way of life in the Neolithic is the reason for the first evidence of anthropisation of the landscape, such as deforestation and plant species with an anthropic origin. Vegetation in the Early Neolithic (ca. 5500-4500 cal BC) is characterised by an advance in herbaceous formations with an anthropic origin and a still significant presence of mesophylous forest with hazel, oak, birch, lime, elm, walnut, etc. The economic practices of the Early Neolithic (agriculture and livestock farming) are not documented together in the pollen record at all sites, as in some places the use of wild resources co-exists with pastoralism or agriculture, attesting a wide range of situations possibly deriving from the origins and evolution of the Early Neolithic in the region.

During the Late Neolithic (ca. 4500-3200 cal BC) and the Chalcolithic (ca. 3200-2200 cal BC) the farming economy is consolidated, as shown by the progressive intensification of anthropisation within the spread of cereal-growing and animal husbandry. The forests, that had previously dominated the vegetation were profoundly affected by the phenomenon of sedentarisation and the increasing importance of Neolithic and Chalcolithic farming activity, with the result that areas colonised by herbaceous communities with an anthropic origin became more common. The dominant vegetation type is characteristic of temperate humid conditions, with deciduous forests of hazel, oak, birch, alder, etc. However, in the southern part of the region (to the south of Sierra de Cantabria), vegetation adapted to a drier and warmer climate is detected, with a predominance of holm oak and the increasing importance of box.

Prehistoric communities in the Bronze Age (ca. 2200-900 cal BC) and the Iron Age (ca. 900-200 cal BC) lived in a mostly deforested environment due to farming activity. Both cereal-growing and livestock farming are widely documented in all the deposits and formed the economic bases of these groups. This landscape exhibited deciduous woodland greatly reduced in size, as a consequence of continuing and increasing anthropisation, with some pines in mountain areas and holm oak on poorer soils and warmer areas. However, the landscape was dominated by pastures with an anthropic origin and others with an anthropozoogenic vocation.

\section{Acknowledgments}

S. Pérez-Díaz is currently supported by a post-doctoral research grant (Basque Government) at Toulouse 2 Jean Jaurès University. This study was funded by the Consolider Research Program in Technologies for Evaluation and Preservation of Cultural HeritageTCP-CSD2007-00058. S. Pérez-Díaz is part of the Research Group in Prehistory IT622-13/UFI 11-09 of the University of the Basque Country (UPV/EHU) and Project HAR2011-23716 Nuevos cultivos, nuevos paisajes, funded by the Plan Nacional I + D + I. The palynological studies of the Atxuri and Quinto Real records were funded by the Collective Research Project 'Paléoenvironnement de la Montagne basque“ (French Ministery of Culture, SRA Aquitaine) headed by D. Galop. We also wish thank the two anonymous referees who contributed to improve the manuscript.

\section{References}

Alday, A., Mujika, J.A., 1999. Nuevos datos de cronología absoluta concerniente a Holoceno medio en el área vasca. In: El mundo indígena. XXIV Congreso Nacional de Arqueología, vol. 2. Instituto de Patrimonio Histórico, Murcia, pp. 95-106.
Alday, A., Arrizabalaga, A., Ciprés, P., Ortiz de Urbina, E., Santos-Yanguas, J., Torregaray, E., Vallejo, J.,M., 2006. Historia del País Vasco. Prehistoria y Antigüedad. Hiria, San Sebastián.

Alday, A., Castaños, P., Perales, U., 2012. Quand ils ne vivaient pas seulement de la Chase: preuves de domestication anienne dans les gisements néolithiques d'Atxoste (Pays Basque). L'Anthropologie 116, 127-147.

Arias, P., Altuna, J., 1999. Nuevas dataciones absolutas para el Neolítico de la Cueva de Arenaza (Bizkaia). Munibe (Antropologia-Arkeologia) 51, 161-171.

Aseginolaza, C., Gómez, D., Lizaur, X., Monserrat, G., Morante, G., Salaverría, M.R., Uribe Etxebarria, P.M., 1996. Vegetación de la Comunidad Autónoma del País Vasco. Gobierno Vasco-Eusko Jaurlaritza, Vitoria-Gasteiz.

Barandiarán-Maestu, I., Martí, B., del Rincón, M.A., Maya, J.L., 1998. Prehistoria de la Península Ibérica. Ariel Prehistoria, Barcelona.

Barbier, D., Burnouf, J., Visset, L., 2001. Les diagrammes société/végétation: un outil de dialogue interdisciplinaire pour la compréhénsion des interactions homme/ milieu. Quaternaire 12 (1-2), 103-108.

Bard, E., Arnold, M., Maurice, P., Duprat, J., Moyes, J., Duplessy, J.C., 1987. Retreat velocity of the North Atlantic PolarFront during the last deglaciation determined by C-14 accelerator mass spectrometry. Nature 328 (6133), 791-794.

Berglund, B.E., 1991. The cultural landscape during 6000 years in southern Sweden. The Ystad Project. Ecological Bulletin 41, 1-495.

Beug, H.J., 2004. Leitfaden der Pollenbestimmung für Mitteleuropa und angrenzende Gebiet. Pfeil, München (D).

Birks, H.H., Birks, H.J.B., Kaland, P.E., Moe, D., 1988. The Cultural Landscape. Past, Present and Future. Cambridge University Press, Cambridge.

Boyer-Klein, A., 1985. Analyse pollinique de la Grotte d'Erralla. Munibe (Antropologia-Arkeologia) 37, 45-48.

Boyer-Klein, A., 1984. Analyse polliniques cantabriques au Tardiglaciaire. Revue de Paléobiologie, pp. 33-39. Especial.

Boyer-Klein, A., 1989. Análisis polínico de la cueva de Zatoya. Trabajos de Prehistoria Navarra 8, 231-235.

Bradley, R.S., 1999 Paleoclimatology. Reconstructing Climates of the Quaternary, second ed., vol. 64. Academic Press, San Diego. International Geophysics Series.

Bueno, A., Fernández, J.A., 1991. Acebuchales y lauredales en la costa cantábrica. Lazaroa 121, 273-301.

Burroughs, W.J., 2005. Climate Change in Prehistory. The End of the Reign of Chaos. Cambridge University Press, Cambridge.

Carozza, L., Galop, D., Marembert, F., Monna, F., 2005. Quel statut pour les espaces de montagne durant l'Âge du Bronze?. Regards croisés sue les approches société-environnment dans les Pyrénées occidentales. Documents d'Archeologie Meridionales 28, 7-23.

Carrión, J.S., Fernández, S., González-Sampériz, P., Gil-Romera, G., Badal, E., Carrión, Y., López-Merino, L., López-Sáez, J.A., Fierro, E., Burjachs, F., 2010. Expected trends and surprises in the Lateglacial and Holocene vegetation history at the Ibreian Peninsula and Balearic Islands. Review of Palaeobotany and Palynology 162, 458-475.

Castaños, P., 1997. Estudio arqueozoológico de la fauna de Peña Larga. In: Fernandez Eraso, J. (Ed.), Excavaciones en el abrigo de Peña Larga. Serie Memorias de Yacimietos Alaveses 4. Diputación Foral de Álava, Vitoria-Gasteiz, pp. 127-134.

Corella, J.P., Stefanova, V., El Anjoumi, A., Rico, E., Giralt, S., Moreno, A., PlataMontero, A., Valero-Garcés, B.L., 2013. A 2500-year multi-proxi reconstruction of climate change and human activities in northern Spain: the lake arreo record. Palaeogrography, Palaeoclimatology, Palaeoecology 386, 555-568.

Costa-Tenorio, M., Morla-Juaristi, C., Sainz-Ollero, H., 2005. Los bosques ibéricos. Una interpretación geobotánica. Planeta, Barcelona.

da Silva, D., 2012. Vegetation Response to Holocene Climate Variability in Southwestern Europe (PhD thesis). Universidade de Lisboa, Facultade de Ciências, Dpto, Geologia.

Davis, B.A.S., Brewer, S., Stevenson, A.C., Guiot, J., 2003. The temperature of Europe during the Holocene reconstructed from pollen data. Quaternary Science Reviews 22, 1701-1716.

Diot, M.F., 1992. Études palynologiques des blés sauvages et domestiques issus de cultures expérimentales. In: Anderson, P.C. (Ed.), Préhistoire de l'agriculture: nouvelles approches expérimentales et ethnographiques. Monographie du CRA 6. Centre de Recherches Archéologiques, Éditions du C.N.R.S, Sophia-Antipolis, pp. 107-111.

Duplessy, J.C., Delibrias, G., Turon, J.L., Pujol, C., Duprat, J., 1981. Deglacial warming of the northeastern atlantic ocean: Correlations with the paleoclimatic ecolution of the european continent. Palaeogeography, Palaeoclimatology, Palaeoecology 35, 121-144.

Dupré, M., 1984. El yacimiento prehistórico de la cueva de Ekain (Deba. Guipúzcoa). Palinología de los niveles VII a II. In: Altuna, J., Merino, J.M. (Eds.), El yacimiento prehistórico de la cueva de Ekain (Deba, Guipúzcoa). Sociedad de Estudios Vascos, San Sebastián, pp. 61-63.

Dupré, M., 1988. Palinología y paleoambiente. Nuevos datos españoles. Referencias. Series de Trabajos Varios, vol. 84. Servicio de Investigación Prehistórica, Diputación Provincial de Valencia, Valencia.

Dupré, M., 1990. Análisis polínico de la cueva de Amalda. In: Altuna, J., Baldeon, A., Mariezkurrena, K. (Eds.), La cueva de Amalda (Zestoa, País Vasco). Ocupaciones paleolíticas y post-paleolíticas. Sociedad de Estudios Vascos, San Sebastián, pp. 49-51. Serie B.

Faegri, K., Iversen, J., 1989. Textbook of Pollen Analysis, fourth ed. (Chichester).

Fernández-Eraso, J., 2007/2008. La secuencia del Neolítico en la Rioja Alavesa desde su origen hasta las primeras edades de los metales. Veleia 24-25 (Homenaje a Ignacio Barandiarán-Maestu) II, 669-687. 
Fernández Eraso, J., 2010. La actividad pecuaria en La Rioja Alavesa durante la Prehistoria reciente. Cuadernos de Arqueología de la Universidad de Navarra 18, 159-171.

Fernández-Eraso, J., de Blas, M.A., Delibes, G., García-Gazólaz, J., Iriarte, M.J., Rodanés, J.M., 2009. Mesolítico y Neolítico: pasado, presente y futuro de las investigaciones. In: Llanos, A. (Ed.), Medio siglo de arqueología en el Cantábrico Oriental y su entorno. Diputación Foral de Álava, Vitoria-Gasteiz, pp. 73-114. Actas del Congreso Internacional.

Fletcher, W.J., Sánchez-Goñi, M.F., Peyron, O., Dormoy, I., 2010. Abrupt climate changes of the last deglaciation detected in a Western Mediterranean forest record. Climate of the Past 6, 245-264.

Galop, D., 1998. La forêt, l'homme et le troupeau dans les Pyrénées. 6000 ans d'histoire de l'environnement entre Garonne et Méditerranée. Geode. Laboratoire d'Ecologie Terrestre, Toulouse.

Galop, D., 2005. La conquete de la montagne pyreneenne au Neolithique. Chronologie, rythmes et transformations des paysages a partir des donnees polliniques. In: Guilaine, J. (Ed.), Populations neolithiques et environnements. Seminaire du College de France. Editions Errance, Paris, pp. 279-295.

Galop, D., Tual, M., Monna, F., Dominik, J., Beyrie, A., Marembert, F., 2001. Cinq millenaires de metallurgie en montagne basque. Les apports d'une demarche integree alliant palynologie et geochemie isotopique du plomb. Sud-Ouest Europeen 11, 3-15.

Galop, D., Carozza, L., Marembert, F., Bal, M.C., 2004. Activités agropastorales et climat durant l'Âge du Bronze dans les Pyrénées: L'état de la question à la lumière des donnes environnementales et archéologiques. In: Emprises et déprises agricoles, expension et régression des sociétés entre 3500 et 2500 BP, pp. 107-119. Besancon.

Galop, D., Rius, D., Cugny, C., Mazier, F., 2013. A history of long-term human-environment interactions in the French Pyrenees inferred from the pollen data. In: Lozny, L.R. (Ed.), Continuity and Change in Cultural Adaptation to Mountain Environments: from Prehistory to Contemporary Threats. Springer, New York, pp. 19-30.

García-Antón, M., Ruiz-Zapata, M.B., Ugarte, F.M., 1987. Primeros resultados del análisis geomorfológico-palinológico de la turbera de Saldropo (Alto de Barazar Bizkaia). In: Actas de la VII Reunión sobre el Cuaternario. AEQUA, Santander, pp. 27-30.

Grimm, E.C., 1992. Tilia, Version 2,. Illinois State Musseum. Research and Collection Center, Springfield. IL 62703. USA.

Grimm, E.C., 2004. TGView. Illinois State Museum, Springfield.

Iriarte, M.J., 1994a. El paisaje vegetal de la Prehistoria reciente en el Alto Valle del Ebro y sus estribaciones atlánticas. Datos polínicos. Antropización del paisaje vegetal y primeros estadios de la economía de producción (PhD thesis). Universidad del País Vasco, Vitoria-Gasteiz.

Iriarte, M.J., 1994b. Estudio palinológico del nivel sepulcral del yacimiento arqueológico de Pico Ramos (Muskiz, Bizkaia). Cuadernos de Sección. Prehistoria-Arqueología 5, 161-179.

Iriarte, M.J., 1995a. Análisis palinológico del monumento megalítico de La Boheriza 2 (Karrantza, Bizkaia). Kobie (Serie Paleoantropología) 22, 158-161.

Iriarte, M.J., 1995b. Análisis polínico del yacimiento de Atxa. In: Gil, E. (Ed.), Atxa: Memoria de excavaciones arqueológicas (1982-1988). Diputación Foral de Alava, Vitoria-Gasteiz, pp. 428-432.

Iriarte, M.J., 1997a. El entorno arqueobotánico del abrigo de Peña Larga. Análisis palinológico. In: Fernandez Eraso, J. (Ed.), Excavaciones en el abrigo de Peña Larga, Serie Memorias de Yacimietos Alaveses 4. Diputación Foral de Álava, Vitoria-Gasteiz, pp. 137-146.

Iriarte, M.J., 1997b. El entorno vegetal del yacimiento de Buruntza (Andoain, Gipuzkoa): datos polínicos. Munibe (Antropologia-Arkeologia) 49, 135-142.

Iriarte, M.J., 1997c. El entorno arqueobotánico de la estación megalítica de AtaunBurunda (Gipuzkoa). I Los dólmenes de Praalata y Aitxu (Ataun-Idiazabal). Isturitz 7, 131-143.

Iriarte, M.J., 1998. Análisis palinológico del depósito arqueológico de Kanpanoste Goikoa (Virgala, Alava). In: Alday, A. (Ed.), Kanpanoste Goikoa. Memoria de las actuaciones arqueológicas. 1992-1993. Diputación Foral de Álava, Vitoria-Gasteiz, pp. 85-91. Serie Memorias de Yacimietos Alaveses 5.

Iriarte, M.J., 1999a. Ilso Betaio: análisis palinológico del poblado prehistórico y de la ferrería altomedieval. Isturitz 10, 175-185.

Iriarte, M.J., 1999b. El entorno arqueobotánico de la estación megalítica de AtaunBurunda (Gipuzkoa). II Los dólmenes de Unanabi y Napalatza (Idiazabal) y el túmulo de Txoritegi (Zarain). Isturiz 10, 247-258.

Iriarte, M.J., 1999c. Análisis palinológico del dolmen de La Cabaña 4 (Karrantza, Bizkaia). Isturitz 10, 242-245.

Iriarte, M.J., 2000. Estudio palinológico de la cueva de Kobeaga II. Illunzar 4, $171-172$.

Iriarte, M.J., 2001. El entorno vegetal de los pobladores prehistóricos de Aizpea: análisis polínico. In: Barandiarán Maestu, I., Cava, A. (Eds.), Cazadores-recolectores en el pirineo navarro. El sitio de Aizpea entre 8000 y 6000 años antes de ahora. Veleia, Anejos Serie Mayor, 10. U.P.V, Vitoria-Gasteiz, pp. 315-324.

Iriarte, M.J., 2006. El entorno vegetal del abrigo de Mendandia y su depósito arqueológico: análisis palinológico. In: Alday, A. (Ed.), El legado arqueologico de Mendandia: Los modos de vida de los últimos cazadores en la Prehistoria de Treviño. Junta de Castilla y Leon, Burgos, pp. 405-418.

Iriarte, M.J., 2007/2009. El Holoceno Medio en el Urdaibai. Illunzar 7, 143-148.

Iriarte, M.J., 2009a. Vegetation landscape and the anthropisation of the environment in the Central sector of the Northern Iberian Peninsula: current status. Quaternary International 200,66-76.
Iriarte, M.J., 2009b. Informe del estudio palinológico del yacimiento arqueológico de Santa María la Real de Zarautz (País Vasco). El paisaje vegetal. In: Ibañez, A (Ed.), Santa María la Real de Zarautz (País Vasco). Continuidad y discontinuidad en la ocupación de la costa vasca entre los siglos V a. C. y XVI d. C. Sociedad de Ciencias Aranzadi, San Sebastián, pp. 118-131. Munibe, Suplemento 27.

Iriarte, M.J., 2011. Polen y vegetación en la secuencia estratigráfica de Santimamiñe (Kortezubi, Bizkaia). In: López-Quintana, J.C. (Ed.), La cueva de Santimamiñe: Revisión y actualización. Diputación Foral de Bizkaia, Bilbao, pp. 321-342.

Iriarte, M.J., Mujika, J.A., Tarriño, A., 2004. Herriko Barra (Zarautz-Guipuzkoa): Caractérisation industrielle et économique des premiers groupes de producteurs sur le littoral Basque. In: Actas del Colloque Unité et diversité des processus de néolithisation sur la façade atlantique de l'Europe, vol. XXXVI Bulletin de la Société Préhistorique Française, pp. 127-136.

Iriarte, M.J., Muñoz-Sobrino, C., Gomez-Orellana, L., Ramil-Rego, P., 2006. Dinámica del paisaje en la Reserva de la Biosfera de Urdaibai durante el Holoceno. In: Cadinanos, J.A., Ibabe, A., Lozano, P., Meaza, G., Onaindia, M. (Eds.), Actas del II Congreso Español de Biogeografía. Reserva de la Biosfera de Urdaibai, 2004. Servicio de Publicaciones del Gobierno Vasco, pp. 113-117.

Iriarte, M.J., Pérez-Díaz, S., Ruiz-Alonso, M., Zapata-Peña, L., 2007/2008. Paleobotánica del Epipaleolítico y Mesolítico vascos. Veleia 24-25, 629-642.

Isturiz, M.J., 1994. Estudio palinológico del yacimiento de Laminak II (Berriartua, Bizkaia). Kobie (Serie Paleoantropología) 21, 166.

Isturiz, M.J., 1997. Análisis palinológico del yacimiento arqueológico de Kukuma (Araia, Alava). In: Baldeon, A., Berganza, E. (Eds.), El yacimiento epipaleolítico de Kukuma. Un asentamiento de cazadores-recolectores en la llanada Alavesa (Araia, Alava), Serie Memorias de Yacimietos Alaveses 3. Diputación Foral de Álava, Vitoria-Gasteiz, pp. 71-73.

Isturiz, M.J., Sanchez-Goñi, M.F., 1990. Investigaciones palinológicas en la Prehistoria vasca. Munibe (Antropologia-Arkeologia) 42, 277-285.

Jalut, G., Turu i Michels, V., Dedoubat, J.J., Otto, T., Ezquerra, J., Fontugne, M. Belet, J.M., Bonnet, L., García de Celis, A., Redondo-Vega, J.M., Vidal-Romaní, J.R. Santos, L., 2010. Palaeoenvironmenal studies in NW Iberia (Cantabrian range): Vegetatation history and synthetic approach of the last deglaciation phases in the western Mediterranean. Palaeogeography, Palaeoclimatology, Palaeoecology 297, 330-350.

López-García, P., 1982. Abauntz, análisis polínico. Trabajos de Arqueología Navarra 2, $355-358$

López-García, P., 1991/1992. Estudio palinológico de los sedimentos del yacimiento de La Peña. Trabajos de Arqueología Navarra 10, 143-145.

López-Sáez, J.A., López-Merino, L., 2005. Precisiones metodológicas acerca de los indicios paleopalinológicos de agricultura en la Prehistoria de la Península Ibérica. Portugalia 26, 53-64.

López-Sáez, J.A., van Geel, B., Martín-Sánchez, M., 2000. Aplicación de los microfósiles no polínicos en Palinología Arqueológica. In: Oliveira Jorge, V., (Coord) (Eds.), Contributos das Ciências e das Technologias para a Arqueologia da Península Ibérica. Actas $3^{\circ}$ Congresso de Arqueologia Peninsular, vol. IX. Adecap, Porto, Vila-Real, Portugal, pp. 11-20 setembro de 1999.

López-Sáez, J.A., López-García, P., Burjachs, F., 2003. Arqueopalinología: Síntesis crítica. Polen 12, 5-35.

López-Sáez, J.A., Galop, D., Iriarte, M.J., López-Merino, L., 2007/2008. Paleoambiente y antropización en los Pirineos de Navarra durante el Holoceno medio (VI-IV milenios cal BC. Una perspectiva palinológica. Veleia, 24-25 (Homenaje a Ignacio Barandiarán Maestu), vol II, pp. 645-653.

Meaza, G., 1991. La impronta mediterránea en el paisaje vegetal del País vasco. Encinares y carrascales. Boletín de la Asociación de Geógrafos Españoles I, 45-74.

Muñoz-Sobrino, C., Heiri, O., Hazekamp, M., van der Velden, D., kirilova, E.P., GarcíaMoreiras, I., Lotter, A.F., 2013. new data on the Lateglacial period of SW Europe: a high resolution multiproxy record from Laguna de la Roya (NW Iberia). Quaternary Science Reviews 80, 58-77.

Naughton, F., Sánchez-Goñi, M.F., Desprat, S., Turon, J.L., Duprat, J., Malaizé, B. joli, C., Cortijo, E., Drago, T., Freitas, M.C., 2007. Present-day and past (last 25000 years) marine pollen signal off western Iberia. Marine Micropaleonology 62 91-114.

Nieto-Moreno, V., Matínez-Ruiz, F., Giralt, S., Jiménez-Espejo, F., Gallego-Torres, D. Rodrígo-Gámiz, M., García-Orellana, J., Ortega-Huertas, M., de Lange, G.J., 2011. Tracking climate variability in the western Mediterranean during the Late Holocene: a multiproxy approach. Climate of the Past 7, 1395-1414.

Peñalba, M.C., 1987. Analisi polinikoaren emaitzak. Mulisko-Gaina (Gipuzkoa) Munibe (Antropologia-Arkeologia) 39, 107-109.

Peñalba, M.C., 1989. Dynamique de végétation tardiglaciaire et Holocène du centrenord de l'Espagne d'après l'analyse pollinique (PhD thesis). Universidad d'Aix, Marseille.

Peñalver, X., 2008. La Edad del Hierro. Los Vascones y sus vecinos. El último milenio anterior a nuestra era (Txertoa, San Sebastián).

Pérez-Díaz, S., 2012. El paisaje vegetal durante la Prehistoria Reciente en la vertiente mediterránea de Euskal Herria (PhD thesis). Universidad del País Vasco/Euskal Herriko Univertsitatea, Vitoria-Gasteiz. http://hdl.handle.net/10810/10805.

Pérez-Díaz, S., López-Merino, L., López-Saez, J.A., 2007. Paleovegetación durante la Edad del Bronce en La Rioja Alavesa: análisis palinológico del yacimiento de Peña Parda (Laguardia, Alava). Cuadernos de Arqueologia de la Universidad de Navarra 15, 177-192.

Pérez-Díaz, S., López-Sáez, J.A., 2012. Paleopaisaje y dinámica antrópica durante la Protohistoria alavesa. Cuadernos de Arqueología de la Universidad de Navarra 20, 153-183. 
Pérez-Díaz, S., López-Sáez, J.A., 2013. Una ventana al pasado. El estudio palinológico del yacimiento del Bronce Medio de Masparra (Alava). Kobie (Paleoantropología) 32, 187-202.

Ramil, P., Rodríguez, A., Muñoz-Sobrino, C., 1998. Sclerophyllous vegetation dynamics in the north of the Iberian Peninsula during the last 16.000 years. Global Ecology and Biogeography Letters 7, 335-351.

Reille, M., 1992. Pollen et spores d'Europe et d'Afrique du Nord, vol. 3. Laboratoire de Botanique Historique et Palynologie, Marseille.

Ruddiman, W.F., McIntyre, A., 1981. The North Atlantic ocean during the last deglaciation. Palaeogeography, Palaeoclimatology, Palaeoecology 35 (2-4), 145-214.

Sadori, L., 2013. Pollen records, Postglacial/Southern Europe. In: Elias, S.A. (Ed.) Encyclopedia of Quaternary Science. Elsevier, Amsterdam, The Netherlands, pp. $179-188$.

Sadori, L., Bertini, A., Combourieu-Nebout, N., Kouli, K., Mariotti-Lippi, M. Roberts, N., Mercuri, A.M., 2013. Palynology and Mediterranean vegetation history. Flora Mediterranea 23, 141-156.

Sánchez-Goñi, M.F., 1987. Analyse palynologique de la grotte de Lezetxiki (niveaux moustériens) (Guipuzcoa, Pays Basque). Mémoire de D.E.A. Quaternaire. Géologie, Paléontologie Humaine, Préhistorire. Museum Nationale d'Histoire Naturelle, Paris.

Sanchez-Goñi, M.F., 1993. De la taphonomie pollinique à la reconstitution de l'environnement. L'example de la région cantabrique (British Archaeological Reports, International Series, Oxford).

Sanchez-Goñi, M.F., 1996. Vegetation and sea level changes during the Holocene in the estuary of the Bidasoa. Quaternaire 7 (4), 207-219.

Sánchez-Goñi, M.F., 2004. La vegetación contemporánea de los grupos Meso-Neolíticos y Neo-Calcolíticos de Kanpanoste (Vírgala, Alava). In: Cava, A. (Ed.) Kanpanoste (Virgala, Alava), la ocupación prehistórica de Kanpanoste en el contexto de los cazadores-recolectores del Mesolítico, Serie Monografias de Yacimientos Alaveses. Diputación Foral de Álava, Vitoria-Gasteiz, pp. 161-168.

Sesma, J., López-Quintana, J.C., Mujika, J.A., Rodanés, J.M., Vegas, J.I., 2009. El período Calcolítico-Edad del Bronce en el Cantábrico Oriental y su entorno. In: Llanos, A. (Ed.), Medio siglo de arqueología en el Cantábrico Oriental y su entorno. Actas del Congreso Internacional. Diputación Foral de Álava, VitoriaGasteiz, pp. 115-200.

Valdés, L.G., 2009. Gastiburu. El santuario vasco de la Edad del hierro y el territorio cariete del oppidum de Marueleza. Real Academia de la Historia, Madrid.

van Geel, B., 1976. A Palaeoecological Study of Holocene Peat Bog Sections, Based on the Analysis of Pollen, Spores and Macro- and Microscopic Remains of Fungi, Algae, Cormophytes and Animals (PhD. thesis). University of Amsterdam, Amsterdam.

van Geel, B., 1978. A palaeoecological study of Holocene peat bog sections in Germany and The Netherlands. Review of Palaeobotany and Palynology 25,1-120.

van Geel, B., 2006. Fossil ascomycetes in Quaternary deposits. Nova Hedwigia 82 $(3-4), 313-329$.

van Geel, B., Hallewas, D.P., Pals, J.P., 1983. A Late Holocene deposit under the Westfriese Zeedijk near Enkhuizen (Prov of N-Holland, The Netherlands): palaeoecological and archaeological aspects. Review of Palaeobotany and Palynology 38, 269-335.

van Geel, B., Buurman, J. Brinkkemper, O, Schelvis, I, Aptroot, A, van Reenen, G. Hakbijl, T., 2003. Environmental reconstruction of a Roman Period settlement site in Uitgeest (The Netherlands), with special reference to coprophilous fungi. Journal of Archaeological Science 30, 873-883.

Vannière, B. Power, M.J., Roberts, N., Tinner, W.., Carrión, J.S., Magny, M., Bartlein, P. Colombaroli, D., Daniau, A.L., Finsinger, W., Gil-Romera, G., Kaltenrieder, P., Pini, P., Sadori, L., Turner, R., Valsecchi, V., Vescovi, E., 2011. Circum-Mediterranean fire activity and climate changes during the mid Holocene environmental transition (8500-2500 cal. BP). The Holocene 21, 53-73.

Zapata, L., 2002. Origen de la agricultura en el País Vasco y transformaciones en el paisaje: Análisis de los restos vegetales arqueológicos. Kobie (Anejo 4). Diputación Foral de Bizkaia, Bilbao.

Zapata, L., Peña-Chocarro, L., Pérez-Jordá, G., Stika, H.P., 2004. Early neolithic agriculture in the Iberian Peninsula. Journal of World Prehistory 18 (4), 283-325.

Zapata, L., Peña-Chocarro, L., 2013. Crops and people. Diffusion of farming in SouthWestern Europe. In: Blasco Ferrer, E., Francalacci, P., Nocentini, A., Tanda, G. (Eds.), Iberia e Sardegna. Legami linguistici, archeologici e genetici dal Mesolitico all'Età del Bronzo. Proceedings of the International Congress "Gorosti U5b3" (Cagliari-Alghero, June 12-16, 2012), Milan, pp. 277-288. 